\title{
Efficiency of Poultry Manure Biochar for Stabilization of Metals in Contaminated Soil
}

\author{
Jung Eun Lim · Sang Soo Lee · Yong Sik Ok* \\ 계분 바이오차를 이용한 토양 중금속 안정화 효율 평가 \\ 임정은 · 이상수 · 옥용식*
}

Received: 12 September 2014 / Accepted: 1 November 2014 / Published Online: 31 March 2015

(C) The Korean Society for Applied Biological Chemistry 2015

\begin{abstract}
Stabilization of heavy metals such as $\mathrm{Pb}, \mathrm{Cd}, \mathrm{Zn}$, and $\mathrm{Cu}$ was evaluated in contaminated soil treated with poultry manure (PM) as well as its biochars pyrolyzed at $300^{\circ} \mathrm{C}(\mathrm{PBC} 300)$ and $700^{\circ} \mathrm{C}(\mathrm{PBC} 700)$ at the application rates of 2.5, 5.0, and 10.0 $\mathrm{wt} \%$ along with the control, prior to 21-days incubation. After incubation, soil $\mathrm{pH}$ was increased from 6.94 (control) to 7.51, 7.24, and 7.88 in soils treated with PM $10 \mathrm{wt} \%$, PBC300 $10 \mathrm{wt} \%$, and $\mathrm{PBC} 70010 \mathrm{wt} \%$ treatments, respectively, mainly due to alkalinity of treatments. In the soil treated with PM, the concentrations of the toxicity characteristic leaching procedure (TCLP)-extractable $\mathrm{Pb}, \mathrm{Cd}, \mathrm{Zn}$, and $\mathrm{Cu}$ were increased by up to $408,77,24$, and $955 \%$, respectively, compared to the control. These increases may possibly be associated with an increased dissolved organic carbon concentration by the PM addition. However, in the soil treated with PBC700, TCLP-extractable Pb, $\mathrm{Cd}, \mathrm{Zn}$, and $\mathrm{Cu}$ concentrations were reduced by up to $23,38,52$, and $36 \%$, respectively, compared to the control. Thermodynamic modelling using the visual MINTEQ was done to predict the precipitations of $\mathrm{Pb}(\mathrm{OH})_{2}, \mathrm{Cu}(\mathrm{OH})_{2}$ and P-containing minerals, such as chloropyromorphite $\left[\mathrm{Pb}_{5}\left(\mathrm{PO}_{4}\right)_{3} \mathrm{Cl}\right]$ and hydroxypyromorphite $\left[\mathrm{Pb}_{5}\left(\mathrm{PO}_{4}\right)_{3} \mathrm{OH}\right]$, in the PBC700 $10 \mathrm{wt} \%$ treated soil. The SEMelemental dot mapping analysis further confirmed the presence of
\end{abstract}

J. E. Lim · S. S. Lee · Y. S. Ok

Korea Biochar Research Center \& Department of Biological Environment, Kangwon National University, Chuncheon 200-701, Republic of Korea

*Corresponding author (Y. S. Ok: soilok@kangwon.ac.kr)

This is an Open Access article distributed under the terms of the Creative Commons Attribution Non-Commercial License (http://creativecommons. org/licenses/by-nc/3.0/) which permits unrestricted non-commercial use, distribution, and reproduction in any medium, provided the original work is properly cited.
Pb-phosphate species via dot mapping of PBC700 treated soil. These results indicate that the reduction of $\mathrm{Pb}$ concentration in the PBC700 treated soil is related to the formations of chloropyromorphite and hydroxypyromorphite which have very low solubility.

Keywords amendment $\cdot$ black carbon $\cdot$ charcoal $\cdot$ metal stabilization $\cdot$ poultry manure $\cdot$ pyromorphite

\section{서 론}

중금속으로 인한 토양오염은 인간 건강에 심각한 위협이 되고 있어 전 세계적으로 이에 대한 정화복원 연구들이 지속적으로 수행되고 있다(Kumpiene 등, 2008; Ok 등, 2010; Almaroai 등, 2014b). 중금속은 유기오염물질과 달리 분해가 되지 않는 물질 고유의 특성상 주로 토양 세척법(soil washing), 굴착 (excavation), 동전기법(electrokinetic separation) 등 물리 - 화학 적인 방법으로 정화가 이루어져 왔다(Kumpiene 등, 2008; Ahmad 등, 2012d; Lim 등, 2013a). 그러나 이러한 방법들은 정화 비용이 많이 소모될 뿐만 아니라 중금속의 농도를 법적 기준 이하로 낮추는 데에만 목적을 두고 있어 정화 후에는 토 양이 가진 고유의 생태적 기능을 상실하게 된다 $(\mathrm{Ok}$ 등, $2011 \mathrm{~b}$; Almaroai 등, 2012). 이에 최근에는 토양으로부터 용출이 용이한 형태의 중금속 농도를 감소시킴으로써 생물유효도(bioavailability) 를 낮출 수 있는 중금속 안정화(metal stabilization) 방법에 대한 연구와 기술개발이 활발히 진행되고 있다 $(\mathrm{Ok}$ 등, $2011 \mathrm{~b}$; $\mathrm{Abd}$ El-Azeem 등, 2013).

중금속 안정화를 위하여 토양 개량제로 사용되는 물질로는 석회질 폐자원(lime-based waste materials)을 들 수 있다. 그 예로는 비산재(Kostarelos 등, 2006), 적니(red mud), 고로슬래그 
(Lee 등, 2009), cement kiln dust(Moon 등, 2008), 굴껍질(Ok 등, 2011a; Lee 등, 2013), 소성 굴껍질(Moon 등, 2011), 달걀 껍질, 닭뼈 ( $\mathrm{Lim}$ 등, 2013b), 홍합껍질, 소뼈 (Ahmad 등, 2012c) 등이 있으며 이들은 주로 토양의 $\mathrm{pH}$ 를 상승시키는 물질이다. 토양의 $\mathrm{pH}$ 가 상승하는 경우 토양의 음전하(negative charge) 증 대를 통해 양이온성 중금속의 토양 흡착이 증가한다(Zhao와 Masaihiko, 2007). 또한 토양 $\mathrm{pH}$ 가 알칼리 조건인 경우 중금속 양이온은 수산화물 침전을 형성하면서 안정화될 수 있다(Zhao 와 Masaihiko, 2007; Ok 등, 2010). 이 외에도 납의 안정화를 위해 인 함유물질(phosphorus-containing materials)을 사용하는 경우 불용성의 pyromorphite $\left[\mathrm{Pb}_{5}\left(\mathrm{PO}_{4}\right)_{3} \mathrm{X} ; \mathrm{X}=\mathrm{Cl}, \mathrm{OH}, \mathrm{F}, \mathrm{Br}\right.$ 등 $]$ 가 형성되며 이 경우 생물유효도는 매우 낮아지는 것으로 알려 져 있다(Kumpiene 등, 2008). 최근에는 바이오차(Biochar)를 토 양 개량제로 활용한 중금속 안정화 연구들이 보고되고 있다 (Ahmad 등, 2014a; 2014b; Mohan 등, 2014).

바이오차는 산소 $\left(\mathrm{O}_{2}\right)$ 가 제한된 조건에서 바이오매스(biomass) 를 $700^{\circ} \mathrm{C}$ 이하의 온도로 열분해하였을 때 생성될 수 있으며, 다른 유기물질에 비해 탄소 $(\mathrm{C})$ 의 함량이 상대적으로 높은 것으 로 알려져 있다(Lehmann과 Joseph, 2009; Lim 등, 2014). 특 히, 바이오차를 토양에 투입하는 경우 탄소의 지중 저장이 가 능하다고 알려져 있으며(Lehmann, 2007), 이 외에도 토양 투입 에 의한 토양질(soil quality) 개선효과(Glaser 등, 2002)와 토양 및 수질 내 유-무기 오염물질의 정화·제거 효과(Uchimiya 등, 2010a; Cao 등, 2011; Ahmad 등, 2012b; 2014a)가 우수 한 것으로 보고되고 있다. 바이오차를 생산하기 위한 원료는 목 질계(lignocellulosic) 바이오매스 및 축분(manure) 등이 있으며 부산물로 발생하는 대부분의 바이오매스가 사용될 수 있다 (Amonette와 Joseph, 2009). 그 예로는 옥수수, 콩, 땅콩 줄기 등과 같은 농업 부산물(Yuan 등, 2011; Ahmad 등, 2012b)과 계분, 우분과 같은 축산업 부산물(Uchimiya 등, $2010 \mathrm{~b}$; Cantrell 등, 2012) 및 하수슬러지와 같은 유기성 부산물(Khan 등, 2013) 등이 있다.

우리나라의 가축분뇨 발생량은 2012년에 4,649만톤으로, 이 중 우분뇨(한육우+젖소)는 약 2,100 만톤으로 전체의 $45.1 \%$ 이며 돈분뇨 1,775 만톤(38.2\%), 계분뇨 656 만톤 $(14.1 \%)$, 기타 119 만 톤 $(2.6 \%)$ 에 달한다(MAFRA, 2013). 가축분뇨의 경우 질소 $(\mathrm{N})$, 인(P)과 같은 양분을 다량으로 함유하고 있어(Cao와 Harris, $2010)$ 퇴비 및 액비로 활용하는 자원화 방법 $(88.7 \%)$, 개별처리 및 공공처리장에서 정화 후 방류하는 방법 $(9.1 \%)$ 들을 통해 처 리되고 있다(MAFRA, 2013). 그러나 최근 가축 사육두수의 증 가로 인해 분뇨 발생량 또한 증가 추세에 있어 이에 대한 추가 적인 처리 및 활용방안이 요구되고 있다(MAFRA, 2013).

이에 본 연구에서는 계분에 대한 추가적인 활용방안 모색을 위해 토양 양분 공급이 기대되는 계분과 토양의 $\mathrm{pH}$ 를 상승시 킬 것으로 예상되는 계분 바이오차를 중금속 $(\mathrm{Pb}, \mathrm{Cd}, \mathrm{Zn}, \mathrm{Cu})$
오염토양에 처리하였다. 이 후 계분 및 계분 바이오차의 특성 평가를 실시하고, 토양의 화학성 분석을 통해 계분 및 계분 바 이오차의 토양 양분 공급 효과를 평가하였다. 또한 대표적 오 염물질 용출시험법인 TCLP(Toxicity characteristics leaching procedure)를 통해 토양 내 중금속 안정화 효율을 평가하였다. 이와 함께 열역학 모델링을 실시하여 중금속 안정화 물질의 형 성을 예측한 후 SEM-elemental dot mapping을 이용한 토양 내 원소분포 조사를 통해 중금속 안정화 기작을 규명하고자 하 였다.

\section{재료 및 방법}

오염토양. 본 연구에서 사용한 토양은 강원도 원주시 신림면에 소재한 석광광산 인근의 밭토양이다. 이곳은 하천변에 방치되어 있는 광미가 강우에 의해 유실되면서 서서히 흘러나와 하류에 위치한 토양이 중금속으로 오염된 지역이다. 토양은 표토(0-15 $\mathrm{cm}$ )를 채취하여 실험실로 운반하였으며 풍건(air drying)한 후 $2 \mathrm{~mm}$ 이하로 체거름을 실시하여 기본 특성 분석 및 계분 바이 오차를 적용하여 항온배양을 실시하였다. 비중계법(hydrometer method)으로 분석한 토양의 토성(soil texture)은 모래(sand), 미사 (silt), 점토(clay)의 함량이 각각 41.5, 40.0, 18.5\%인 양토(loam) 이며(Gee와 Or, 2002), $\mathrm{pH}$ 가 7.0인 중성토양이었다. 토양의 유 효인산 $\left(\right.$ Avail. $\left.\mathrm{P}_{2} \mathrm{O}_{5}\right)$ 과 치환성 칼슘(Exc. Ca) 함량은 우리나라 농경지 밭토양의 양분 최적범위를 약간 상회하는 수준인 것으 로 나타났다(NAAS, 2014). 토양 내 중금속의 총 함량을 왕수 (aqua regia) 분해 후 유도결합플라즈마발광광도계(ICP-OES, Thermo iCAP6300, England)로 분석한 결과 납, 카드뮴, 아연, 구리가 각각 $1389.9,6.6,862.7,300.6 \mathrm{mg} / \mathrm{kg}$ 로 나타났다. 이 는 우리나라 토양오염우려기준의 농경지(1지역: 전 - 답·과수 원 등) 기준치 $(\mathrm{Pb}: 200 \mathrm{mg} / \mathrm{kg}, \mathrm{Cd}: 4 \mathrm{mg} / \mathrm{kg}, \mathrm{Zn}: 300 \mathrm{mg} / \mathrm{kg}$, $\mathrm{Cu}: 150 \mathrm{mg} / \mathrm{kg}$ )를 모두 상회하고 있는 오염 수준이다(MOE, 2014) (Table 1).

계분 및 계분 바이오차. 본 연구에서 사용된 계분 시료의 수집 과 바이오차의 생산방법은 다음과 같다. 계분 시료는 경기도 가 평군 설악면 소재의 계분퇴비공장에서 채취하였으며, 공장 내 양계장에서 발생하여 퇴비생산을 위한 부숙화 공정에 투입되기 직전의 생분(fresh manure)을 채취하였다. 채취 후에는 1 주 이 상 풍건을 실시하고 고무망치로 파쇄하여 $2 \mathrm{~mm}$ 이하로 체거름 한 것을 시료로 사용하였다. 바이오차의 생산방법은 다음과 같 다. 앞서 체거름한 계분시료를 도가니(crucible)에 담고 덮개를 덮은 상태로 제한적 산소 조건에서 열분해를 실시하였다. 열분 해 최고온도(HTT, highest treatment temperature)는 각각 300 과 $700^{\circ} \mathrm{C}$ 로 설정하였고 분당 $7^{\circ} \mathrm{C}$ 의 승온 조건으로 최고 온도 에 도달하게 한 후 2시간을 유지하였다. 이 후 24시간 동안 방

Table 1 Physicochemical properties of selected soil

\begin{tabular}{|c|c|c|c|c|c|c|c|c|c|c|c|}
\hline \multirow{3}{*}{$\begin{array}{l}\text { Soil } \\
\text { texture }\end{array}$} & \multirow{2}{*}{$\mathrm{pH}$} & \multirow{2}{*}{$\begin{array}{c}\mathrm{EC}^{\mathrm{a}} \\
(1: 5)\end{array}$} & \multirow{2}{*}{$\mathrm{OM}^{\mathrm{b}}$} & \multirow{2}{*}{ Avail. $\mathrm{P}_{2} \mathrm{O}_{5}$} & \multicolumn{3}{|c|}{ Exc. cations } & \multicolumn{4}{|c|}{ Heavy metals (total concentration) } \\
\hline & & & & & $\mathrm{Ca}$ & $\mathrm{K}$ & $\mathrm{Mg}$ & $\mathrm{Pb}$ & $\mathrm{Cd}$ & $\mathrm{Zn}$ & $\mathrm{Cu}$ \\
\hline & $(1: 5)$ & $\mathrm{dS} / \mathrm{m}$ & $\mathrm{g} / \mathrm{kg}$ & $\mathrm{mg} / \mathrm{kg}$ & \multicolumn{3}{|c|}{ - } & \multicolumn{4}{|c|}{ 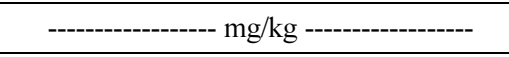 } \\
\hline Loam & 7.0 & 0.5 & 31.2 & 404.7 & 10.5 & 0.4 & 2.0 & 1389.9 & 6.6 & 862.7 & 300.6 \\
\hline- & $6.0-6.5^{\mathrm{c}}$ & $0-2.0^{\mathrm{c}}$ & $20-30^{\mathrm{c}}$ & $150-250^{\mathrm{c}}$ & $5.0-6.0^{\mathrm{c}}$ & $0.45-0.55^{\mathrm{c}}$ & $1.5-2.5^{\mathrm{c}}$ & $200^{\mathrm{d}}$ & $4^{\mathrm{d}}$ & $300^{\mathrm{d}}$ & $150^{\mathrm{d}}$ \\
\hline
\end{tabular}

${ }^{\mathrm{a}}$ Electrical conductivity; ${ }^{\mathrm{b} O r g a n i c}$ matter; ${ }^{\mathrm{c} O p t i m u m}$ range (NAAS, 2014); ${ }^{\mathrm{d}}$ The Korean warning standard for agricultural land (MOE, 2014). 
랭한 후 생산된 바이오차를 시료로 사용하였다. 본 연구에 사용 된 계분 시료는 $\mathrm{PM}$ (poultry manure), $\mathrm{PBC} 300$ (poultry manure biochar pyrolyzed at $300^{\circ} \mathrm{C}$ ), $\mathrm{PBC} 700$ (poultry manure biochar pyrolyzed at $700^{\circ} \mathrm{C}$ )으로 명명하였다.

PM, PBC300, PBC700의 특성 평가. PM, PBC300, PBC700 의 공업 분석(proximate analysis)은 다음과 같이 실시하였다. 수 득률(yield)은 열분해 전 - 후의 시료무게로 산출하였고(식 1), $\mathrm{PM}, \mathrm{PBC} 300, \mathrm{PBC} 700$ 에 대해 $105^{\circ} \mathrm{C}$ 에서 24 시간 건조, $450^{\circ} \mathrm{C}$ 에서 30 분 가열, $750^{\circ} \mathrm{C}$ 에서 30 분의 가열과정을 연속적으로 실 시하여 식 2-5의 계산을 통해 수분함량(moisture), 휘발분 (mobile matter), 회분(ash), 고정탄소(resident matter) 함량을 산 출하였다(Ahmad 등, 2012b; Lim 등, 2014).

식 1) 수득률 $(\%)=($ 열분해 후 시료의 무게 $/$ 열분해 전 시료의 무게)*100

식 2) 수분함량 $(\%)=\left[\left(105^{\circ} \mathrm{C}\right.\right.$ 건조 전 시료의 무게 $-105^{\circ} \mathrm{C}$ 건 조 후 시료의 무게 $) / 105^{\circ} \mathrm{C}$ 건조 전 시료의 무게 $]^{*} 100$

식 3) 휘발분 $(\%)=\left[\left(450^{\circ} \mathrm{C}\right.\right.$ 가열 전 시료의 무게 $-450^{\circ} \mathrm{C}$ 가열 후 시료의 무게 $) / 450^{\circ} \mathrm{C}$ 가열 전 시료의 무게 $]^{*} 100$

식 4) 회분 $(\%)=\left(750^{\circ} \mathrm{C}\right.$ 가열 후 시료의 무게 $/ 750^{\circ} \mathrm{C}$ 가열 전 시료의 무게 $) * 100$

식 5) 고정탄소 $(\%)=100$-(수분함량+휘발분+회분)

$\mathrm{PM}, \mathrm{PBC} 300, \mathrm{PBC} 700$ 의 $\mathrm{pH}$ 와 전기전도도 $(\mathrm{EC}$, electrical conductivity) 분석은 다음과 같이 실시하였다. $\mathrm{pH}$ 는 시료와 증 류수를 1:10 비율로 혼합하여 30 분간 교반한 후 $\mathrm{pH}$ meter (Inolab pH $7110 \mathrm{BNC}, \mathrm{WTW}, \mathrm{Germany}$ 로 측정하였다. EC는 $\mathrm{pH}$ 측정 후 혼탁액을 Whatman No. 2 여과지 $(8 \mu \mathrm{m})$ 에 여과한 후 $\mathrm{EC}$ meter (Orion 3 star, Thermo, USA)로 측정하였다 (Ahmad 등, 2012b).

원소 분석(ultimate analysis)은 원소 분석기(Flash EA 1112, Thermo, USA)를 이용하여 탄소, 수소 $(\mathrm{H})$, 산소 $(\mathrm{O})$, 질소, 황 $(\mathrm{S})$ 의 함량을 분석하였으며, 각 원소 함량에 기초하여 방향성 및 극성의 정도를 유추할 수 있는 $\mathrm{H} / \mathrm{C}$ 및 $\mathrm{O} / \mathrm{C}$ atomic ratio를 산 출하였다.

$\mathrm{PM}, \mathrm{PBC} 300, \mathrm{PBC} 700$ 의 $\mathrm{BET}$ 비표면적 및 공극 부피 분석 (surface area and pore volume)은 Particle and pore size analysis system (Accelerated Surface Area and Porosimetry System, ASAP 2010, USA)을 이용하여 실시하였다.

$\mathrm{PM}, \mathrm{PBC} 300, \mathrm{PBC} 700$ 의 중금속 총 함량분석은 다음과 같이 실시하였다. 왕수를 시료와 혼합하고 16 시간동안 상온에서 정 치시킨 후 2 시간 동안 $130^{\circ} \mathrm{C}$ 에서 분해하였다. 이 후 Whatman No. 41 여과지 $(20 \mu \mathrm{m})$ 로 여과하고 $0.5 \mathrm{M}-\mathrm{HNO}_{3}$ 로 희석하여 $\mathrm{ICP}-\mathrm{OES}$ 로 중금속을 분석하였다.

$\mathrm{PM}, \mathrm{PBC} 300, \mathrm{PBC} 700$ 의 작용기 분석은 푸리에 변환 적외선 분광기(FT-IR, fourier transform infrared spectrometer) (FT-3000 $\mathrm{MX}, \mathrm{BIO}-\mathrm{RAD}, \mathrm{USA}$ )를 이용하여 scan range $650-3200 \mathrm{~cm}^{-1}$ 에 대해 resolution $4 \mathrm{~cm}^{-1}$, scan number 32 로 측정하여 얻어진 스 펙트럼을 Coates (2000)의 방법에 준하여 해석하였다.

한편, $\mathrm{PM}$ 의 바이오차 생산과정 중 열분해에 의한 $\mathrm{PM}$ 의 중 량변화 및 열적 안정성을 평가하기 위하여 열중량분석기(SDT Q600, TA instrument, USA)로 열중량 분석(TGA, thermogravimetric analysis)을 실시하였다. 분석 시 약 $16.88 \mathrm{mg}$ 의 $\mathrm{PM}$ 을 사용하였 으며 바이오차 생산과 동일하게 분당 $7^{\circ} \mathrm{C}$ 의 승온속도로 $1000^{\circ} \mathrm{C}$ 까지 가열하면서 분석하였다.
항온배양실험. $\mathrm{PM}$ 및 $\mathrm{PBC} 300, \mathrm{PBC} 700$ 처리에 의한 토양 내 중금속의 안정화 효율과 토양의 화학적 특성변화를 평가하기 위 해 항온배양실험을 실시하였다. 오염토양 $150 \mathrm{~g}$ 을 고밀도폴리에 틸렌(HDPE, high-density polyethylene) 재질의 배양병에 담고 중금속 안정화 처리제로서 $\mathrm{PM}, \mathrm{PBC} 300, \mathrm{PBC} 700$ 을 토양 무게 기준으로 $2.5,5,10 \mathrm{wt} \%$ 를 담고 균일하게 혼합하였다. 처리제와 혼합된 토양은 항온배양기(Cooled incubator, MIR-554, Sanyo, Japan) 내부에서 21 일간 $25^{\circ} \mathrm{C}$ 를 유지하면서 배양하였다. 배양기 간 동안 처리제와 토양 간의 반응이 원활히 이루어질 수 있도 록 토양의 수분을 보수력(WHC, water holding capacity)의 $70 \%$ 수준으로 유지하였다(Ahmad 등, 2012a). 항온배양실험은 3 반복으로 수행되었으며 21일 후 토양 시료를 배양기에서 꺼내 어 풍건한 후 분석을 위해 사용하였다.

토양 화학성 평가. $\mathrm{PM}, \mathrm{PBC} 300, \mathrm{PBC} 700$ 의 토양 처리 21일 후 토양의 화학적 특성변화를 평가하기 위하여 토양 및 식물체 분석법(NIAST, 2000)에 준하여 분석을 실시하였다. 토양의 $\mathrm{pH}$ 와 EC는 $1_{\text {soil }}: 5_{\text {water }}$ 법, 유기물(OM, organic matter) 함량은 Tyurin법, 총 질소(T-N)는 원소분석기(vario MAX CN, Elementar, Germany) 로 분석하였다. 또한 유효인산은 Lancaster법, 치환성 양이온 (Exc. cations)은 $1.0 \mathrm{~N}-\mathrm{NH}_{4} \mathrm{OAc}(\mathrm{pH}$ 7.0)으로 용출한 후 여과 액을 ICP-OES로 분석하였다.

TCLP에 의한 중금속 용출시험. TCLP는 폐기물 용출시험법으 로 액상(liquid), 고상(solid), 및 다상(multiphasic) 폐기물에 존재 하는 유-무기 분석대상물질의 이동성을 평가할 수 있으며, 일 반적으로 오염토양 정화 후 중금속 안정화 효율을 평가하기 위 하여 사용하는 방법이다(USEPA, 1992). 본 연구에서는 PM, $\mathrm{PBC} 300, \mathrm{PBC} 700$ 의 토양 처리 후 중금속 안정화 효율을 평가 하기 위해 TCLP를 수행하였다. 토양 $2 \mathrm{~g}$ 을 HDPE 용기에 취한 뒤 혼합추출용매 \#1 (pH 4.93) $40 \mathrm{~mL}$ ( $1_{\text {solid }}: 20_{\text {liquid }}$ 비율)을 가 하였다. 이 후 $23^{\circ} \mathrm{C}$ 를 유지하면서 $30 \mathrm{rpm}$ 에서 18 시간 진탕한 다음 $0.45 \mu \mathrm{m}$ membrane filter로 여과한 용액의 $\mathrm{pH}$ 를 측정하였 으며, ICP-OES를 사용하여 납, 카드뮴, 아연, 구리를 분석하였 다. 한편, 혼합추출용매의 선택방법은 다음과 같다. 토양 $5 \mathrm{~g}$ 에 증류수 $96.5 \mathrm{~mL}$ 를 가하고 마그네틱 교반기로 5 분간 교반한 후 $\mathrm{pH}$ 를 측정하여 $\mathrm{pH}<5.0$ 이면 혼합추출용매 \#1을 사용한다. $\mathrm{pH}>5.0$ 인 경우 $1.0 \mathrm{~N}-\mathrm{HCl} 3.5 \mathrm{~mL}$ 을 다시 가한 뒤 시계접시(watch glass)를 덥고 $50^{\circ} \mathrm{C}$ 에서 10 분간 방치한다. 방랭 10 분 후에는 $\mathrm{pH}$ 를 재측정하여 $\mathrm{pH}<5.0$ 이면 혼합추출용매 \#1을 가하고 $\mathrm{pH}>5.0$ 이면 혼합추출용매 $\# 2$ 를 사용한다. 본 실험에서는 상기 과정을 수행한 후 혼합추출용매 \#1을 사용하였다(USEPA, 1992).

열역학 모델링. 본 연구에서는 $\mathrm{PM}, \mathrm{PBC} 300, \mathrm{PBC} 700$ 을 오염 토양에 처리한 후 형성 가능한 화학종을 예측하고자 열역학 모 델링 프로그램 visual MINTEQ ver. 3.0 (Gustafsson, 2012)을 사용하였다. MINTEQ 프로그램의 구동을 위한 입력값 도출을 위한 분석방법은 다음과 같다. 항온배양을 마친 후 처리제 10 $\mathrm{wt} \%$ 가 적용된 토양 $10 \mathrm{~g}$ 이 담긴 삼각플라스크에 증류수 100 $\mathrm{mL}\left(1_{\text {soil }} 10_{\text {water }}\right)$ 를 가하고 $25^{\circ} \mathrm{C}$ 에서 24 시간 동안 교반하였다 (Ahmad 등, 2012a). 교반 후에는 $0.45 \mu \mathrm{m}$ membrane filter로 여과하여 기기분석을 위한 시료로 사용하였다(Ahmad 등, 2012a). 여액은 pH를 측정하였으며, dissolved organic carbon (DOC)은 총 유기탄소측정기 $\left(\mathrm{TOC}-\mathrm{V}_{\mathrm{CPH}}\right.$, Shimadzu, Japan)로, 양이온 $(\mathrm{Pb}, \mathrm{Cd}, \mathrm{Cu}, \mathrm{Zn}, \mathrm{Al}, \mathrm{Fe}, \mathrm{Ca}, \mathrm{Na}, \mathrm{K}, \mathrm{Mg})$ 은 $\mathrm{ICP}-$ $\mathrm{OES}$ 로, 음이온 $\left(\mathrm{Cl}, \mathrm{NO}_{3}, \mathrm{PO}_{4}, \mathrm{SO}_{4}\right)$ 은 이온크로마토그래프( $\mathrm{IC}$, $\mathrm{DX}-320, \mathrm{Dionex}, \mathrm{USA})$ 를 사용하여 측정하였다. 모든 측정값은 
MINTEQ 프로그램의 구동 시 입력값으로 사용하였다. 이 후 처 리제 별로 주요 화학종에 대한 포화지수(SI, saturation index)를 산출하였다. 이 때 $\mathrm{SI}<-1$ 인 경우, 대상 화학종은 해당계에서 불 포화상태(undersaturation)이며; $-1<\mathrm{SI}<0$ 인 경우, 대상 화학종은 해당계에서 포화상태(saturation)로; $\mathrm{SI}>0$ 인 경우에는 과포화상 태(supersaturation)로서 화학종이 침전(precipitation) 될 가능성이 있는 것으로 평가하였다(Ahmad 등, 2012a).

SEM 및 elemental dot mapping. $\mathrm{PM}, \mathrm{PBC} 300, \mathrm{PBC} 700$ 의 처리에 의한 오염토양의 미세 변화 관찰 및 이에 대한 원소분 포(elemental distribution)를 살펴보기 위해 에너지 분산형 X-선 분광기(EDS, energy dispersive X-ray spectrometer) system (ISIS 310)이 장착된 주사전자현미경(SEM, S-4300 FE-SEM, Hitachi, Japan)으로 elemental dot mapping을 실시하였다. 대상 시료는 $\mathrm{PM}, \mathrm{PBC} 300, \mathrm{PBC} 700$ 이 $10 \mathrm{wt} \%$ 처리된 토양을 풍건 하여 사용하였으며, 이를 양면이 탄소로 코팅된 테이프(doublesided carbon coated tape)에 부착하였다. 이 후 charging 현상 방지를 위해 진공상태에서 백금 $(\mathrm{Pt})$ 코팅을 실시한 후 SEM-EDS 장비 내부의 sample holder에 장착하여 광물학적 형태 (mineralogical form)를 관찰하고 특이 형태에 대한 원소분포( $\mathrm{Si}$, $\mathrm{Al}, \mathrm{O}, \mathrm{P}, \mathrm{Pb}$ )를 조사하였다(Ahmad 등, 2012a).

통계분석. 본 연구에서는 $\mathrm{PM}, \mathrm{PBC} 300, \mathrm{PBC} 700$ 처리에 의한 중금속 안정화 효율과 토양의 화학적 특성 변화 정도를 비교평가 하기 위하여 SAS package (ver. 9.1, SAS institute Inc., Cary, $\mathrm{NC}, \mathrm{USA}$ )를 이용한 ANOVA 검정을 실시하였다. ANOVA 검 정은 각 처리구 내에서 반복시료에 대한 분석값을 산출하고 처 리구 사이의 유의성 $(P<0.05)$ 을 검정하였다. 또한 평가 항목간 상관관계는 Pearson's correlation coefficient를 산출하여 평가하 였다.

\section{결과 및 고찰}

PM, PBC300, PBC700의 특성. PM, PBC300, $\mathrm{PBC} 700$ 에 대 한 공업 분석 결과 수득률은 $\mathrm{PBC} 300$ 과 $\mathrm{PBC} 700$ 이 각각 65.70 , $47.00 \%$, 휘발분 함량은 $\mathrm{PM}, \mathrm{PBC} 300, \mathrm{PBC} 700$ 이 각각 48.43 , $19.02,4.13 \%$ 로 수득률 및 휘발분 함량 모두 열분해 온도가 상 승함에 따라 감소하는 것으로 나타났다(Table 2). Novak 등 (2009) 및 Cantrell 등(2012)은 바이오차 생산을 위한 열분해 과 정 중 수산기(hydroxyl group)의 탈수작용(dehydration)과 목부 섬유소(ligno-cellulose) 구조의 분해를 통해 휘발성 물질이 제거 되어 휘발분 함량은 급격히 감소하고 이와 함께 수득률도 감소 하게 됨을 보고하였다. 또한 수득률 및 휘발분 함량의 감소는 온도증가에 의한 유기물의 분해와 $\mathrm{CH}_{4}, \mathrm{H}_{2}, \mathrm{CO}$ 의 손실 등에 기인한 것으로 판단된다(Novak 등, 2009; Ahmad 등, 2012b). $\mathrm{PM}, \mathrm{PBC} 300, \mathrm{PBC} 700$ 의 회분함량은 각각 $16.02,24.03$, $24.17 \%$ 였으며, $\mathrm{PBC} 300$ 과 $\mathrm{PBC} 700$ 간의 차이는 없었으나 $\mathrm{PM}$ 과 $\mathrm{PBC} 300, \mathrm{PBC} 700$ 을 비교할 때 열분해에 따른 증가경향이 나타 났다. 선행연구들(Shinogi와 Kanri, 2003; Cao와 Harris, 2010; $\mathrm{Ahmad}$ 등, 2012b)에 의하면 회분함량은 열분해 온도가 상승함 에 따라 증가하는데 이는 분해 및 휘발되지 않는 무기 염류가 열분해 과정에서 회분의 형태로 농축된 것과 유기물질의 열분 해 잔류물 생성에 의한 증가 효과라고 하였으며 본 연구결과도 이에 기인한 것으로 판단된다.

$\mathrm{PM}, \mathrm{PBC} 300, \mathrm{PBC} 700$ 의 $\mathrm{pH}$ 와 $\mathrm{EC}$ 는 각각 $7.24,8.78$,
Table 2 Physiochemical properties of poultry manure (PM), poultry manure biochar pyrolyzed at $300^{\circ} \mathrm{C}(\mathrm{PBC} 300)$ and poultry manure biochar pyrolyzed at $700^{\circ} \mathrm{C}(\mathrm{PBC} 700)$

\begin{tabular}{lcrrr}
\hline \multicolumn{1}{c}{ Parameters } & Unit & PM & PBC300 & PBC700 \\
\hline Yield & wt $(\%)$ & - & 65.70 & 47.00 \\
Moisture & & 5.30 & 0.45 & 1.97 \\
Mobile matter & & 48.83 & 19.02 & 4.13 \\
Ash & & 16.02 & 24.03 & 24.17 \\
Resident matter & & 29.78 & 56.50 & 69.94 \\
$\mathrm{pH}(1: 10)$ & - & 7.24 & 8.78 & 10.70 \\
$\mathrm{EC}(1: 10)$ & $\mathrm{dS} / \mathrm{m}$ & 13.38 & 14.08 & 16.19 \\
$\mathrm{C}^{\mathrm{a}}$ & $\mathrm{wt}(\%)$ & 39.81 & 52.90 & 56.09 \\
$\mathrm{H}^{\mathrm{a}}$ & & 5.59 & 3.92 & 1.52 \\
$\mathrm{O}^{\mathrm{a}}$ & & 48.74 & 34.73 & 37.19 \\
$\mathrm{~N}^{\mathrm{a}}$ & & 5.14 & 7.80 & 4.16 \\
$\mathrm{~S}^{\mathrm{a}}$ & & 0.72 & 0.65 & 1.05 \\
$\mathrm{H} / \mathrm{C}^{\mathrm{b}}$ & - & 1.67 & 0.88 & 0.32 \\
$\mathrm{O} / \mathrm{C}^{\mathrm{b}}$ & & 0.92 & 0.49 & 0.50 \\
Surface area & $\mathrm{m}^{2} / \mathrm{g}$ & 2.915 & 4.340 & 6.617 \\
Pore volume & $\mathrm{cm}^{3} / \mathrm{g}$ & 0.012 & 0.012 & 0.020 \\
\hline
\end{tabular}

${ }^{\mathrm{a}}$ Moisture- and ash-free basis contents; ${ }^{\mathrm{b}}$ Atomic ratio.

10.70 과 $13.38,14.08,16.19 \mathrm{dS} / \mathrm{m}$ 였으며 열분해 온도가 상승함 에 따라 증가하는 것으로 나타났다(Table 2). Shinogi와 Kanri (2003), Ahmad 등(2012b)은 열분해 과정에서 바이오매스 내 유 기물질 중 알칼리성 염이 분리되면서 이로부터 생산되는 바이 오차 자체가 알칼리화됨을 보고한 바 있다. $\mathrm{EC}$ 의 경우 열분해 과정을 통해 휘발성 물질이 손실됨으로써 회분 내 다양한 염 들이 농축되고 이를 통해 $\mathrm{EC}$ 가 증가한 것으로 판단된다(Cantrell 등, 2012; Lim 등, 2014).

원소 분석 결과 $\mathrm{PM}, \mathrm{PBC} 300, \mathrm{PBC} 700$ 의 탄소 함량은 각각 $39.81,52.90,56.09 \%$ 로 $\mathrm{PBC} 700$ 이 가장 높은 것으로 나타났다 (Table 2). 이와 동일하게 Novak 등(2009)은 바이오차의 탄화 (carbonization) 정도가 생산온도의 상승과 함께 증가한다고 하 였으며, Ahmad 등(2012b)도 바이오차 생산온도가 높을 때 탄 화의 정도가 높음을 보고하였다. 한편, 수소와 산소의 함량은 열분해 온도가 상승함에 따라 감소하는 경향으로 나타났다. 이 는 열분해 과정 중 바이오매스의 탈수작용에 의한 수산기 $(-\mathrm{OH})$ 의 손실과 분자구조의 변형을 통해 탄소와 결합한 수소, 산소 원자의 손실에 기인하는 것으로 판단된다(Novak 등, 2009). 특 히, 방향성(aromaticity)과 관련된 $\mathrm{H} / \mathrm{C}$ atomic ratio와 극성 (polarity)과 관련된 $\mathrm{O} / \mathrm{C}$ atomic ratio는 열분해 온도가 상승함에 따라 감소하는 것으로 나타났다. 이는 열분해 과정에서 바이오 매스가 함유한 유기물질의 탄화에 의한 방향성 구조(aromatic structure)의 형성이 증진되었고, 바이오매스의 극성작용기(polar functional group)가 고온에서 감소하면서 나타난 결과로 판단된 다(Uchimiya 등, 2010b; Ahmad 등, 2012b). 질소 함량의 경우, $\mathrm{PBC} 700$ 가 $\mathrm{PM}$ 과 $\mathrm{PBC} 300$ 보다 낮았으며 열분해에 의한 질소 함 유 휘발성 유기물의 손실에 기인한 것으로 판단된다(Chan과 $\mathrm{Xu}$, 2009).

$\mathrm{PM}, \mathrm{PBC} 300, \mathrm{PBC} 700$ 의 비표면적과 공극 부피는 열분해 온 도가 상승함에 따라 증가하는 것으로 나타났다(Table 2). 일반 적으로 바이오차는 열분해 온도가 상승하면 비표면적이 증가하 는 것으로 알려져 있으며 이는 aliphatic alkyl 및 ester group의 
(A)

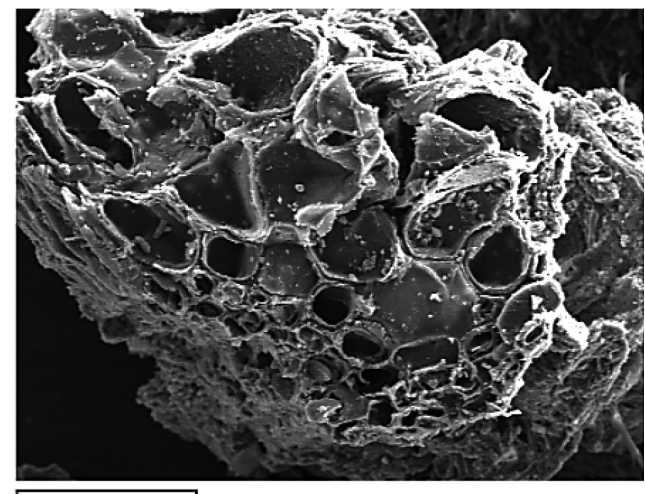

$100 \mu \mathrm{m}$

Electron Image 1

(B)

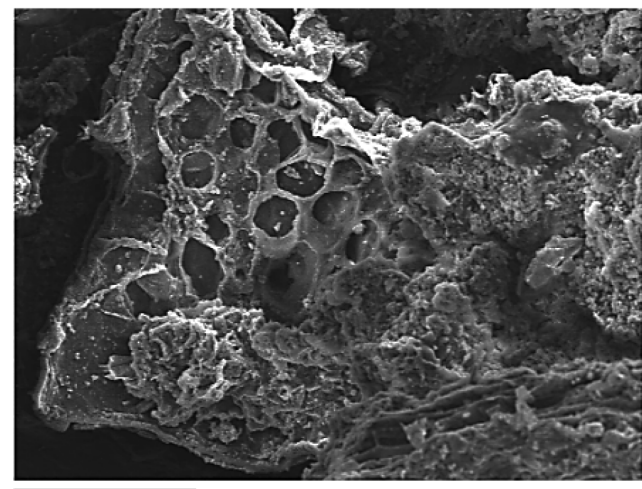

$100 \mu \mathrm{m}$

Electron Image 1

(C)

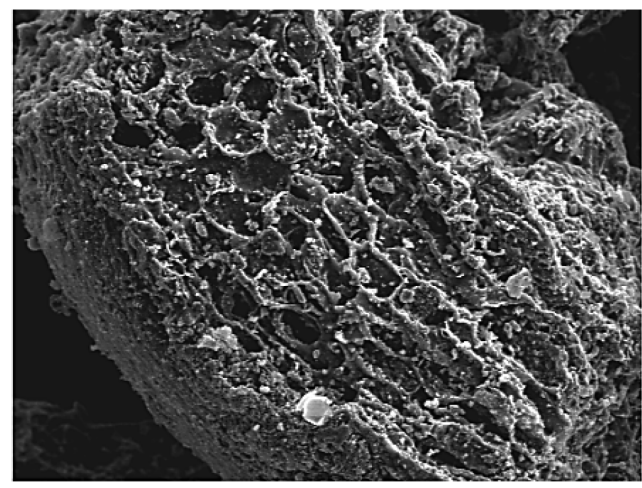

$100 \mu \mathrm{m}$

Electron Image 1

Fig. 1 Scanning electron microscopy (SEM) images of (A) poultry manure (PM), (B) poultry manure biochar pyrolyzed at $300^{\circ} \mathrm{C}(\mathrm{PBC} 300)$ and $(\mathrm{C})$ poultry manure biochar pyrolyzed at $700^{\circ} \mathrm{C}(\mathrm{PBC} 700)$.

분해 등에 기인하는 것으로 보고된 바 있다(Ahmad 등, 2014b). 또한 열분해 과정 중 탈수산작용(dehydroxylation)에 의해 방출 되어 증가된 물 분자가 공극 형성자(pore-former) 및 활성화제 (activation agent)로의 역할을 하게 되고, 이 때 매우 미세한 크 기(nanometer-size)의 공극 형성과 같은 다공성(porosity)의 증대 를 통해 비표면적을 증가시키는데 본 연구결과도 이에 기인한 것으로 판단된다(Chan과 $\mathrm{Xu}, 2009)$. 한편, Zhang 등(2004)은 활성탄(activated carbon)의 생산 시 고온에 의해 원료의 미세공 극(micropore) 사이의 벽이 파괴되어 미세공극이 확장되면서 전 체적인 공극의 부피가 증가한다고 보고하였으며 본 연구에서 나

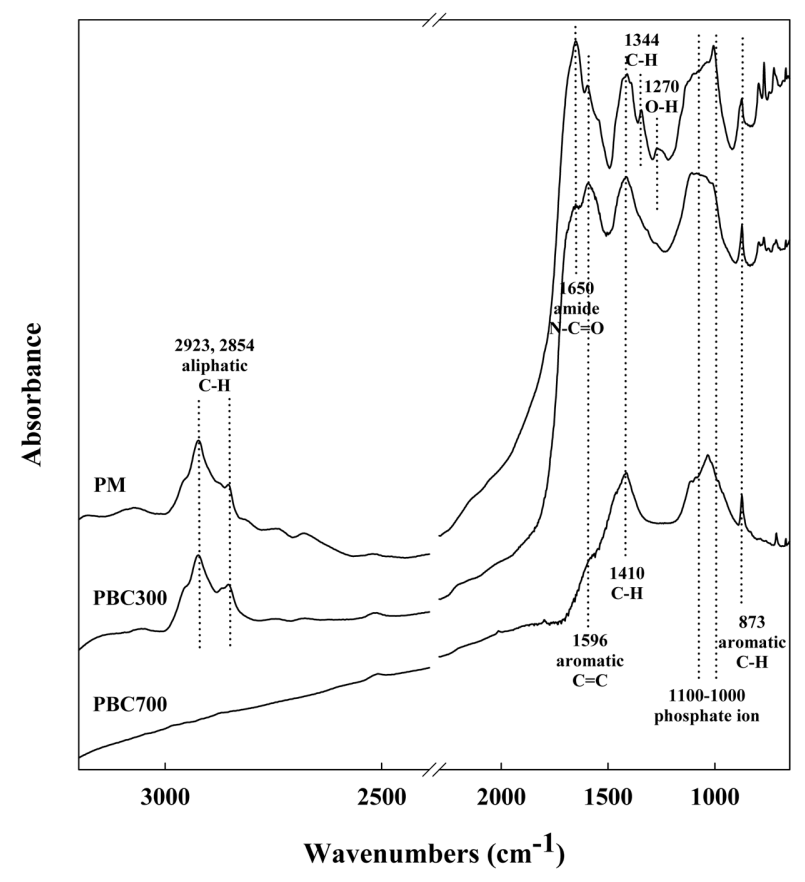

Fig. 2 Fourier transform infrared spectroscopy (FT-IR) spectra of poultry manure (PM), poultry manure biochar pyrolyzed at $300^{\circ} \mathrm{C}(\mathrm{PBC} 300)$ and poultry manure biochar pyrolyzed at $700^{\circ} \mathrm{C}(\mathrm{PBC} 700)$.

타난 열분해 온도 상승에 따른 공극 부피의 증가도 이 같은 현 상에 기인한 것으로 판단된다.

한편, 축산분야에서 구리와 아연은 사료효율 증대, 질병예방 등을 위해 가축 사료의 첨가제로 사용되는데(Adriano, 2001), 이 로 인해 $\mathrm{PM}$ 및 $\mathrm{PBC} 300, \mathrm{PBC} 700$ 에서 구리와 아연이 낮은 수 준으로 검출되었다(data not shown).

$\mathrm{PM}, \mathrm{PBC} 300, \mathrm{PBC} 700$ 표면 특성을 $\mathrm{SEM}$ 으로 관찰한 결과 는 Fig. 1과 같다. 관찰 결과 열분해 온도가 상승함에 따라 표 면에서 상대적으로 미세한 크기의 공극들이 다량으로 관찰되었 다. 이와 유사하게 Ahmad 등(2012b)은 열분해를 통해 휘발성 물질들이 제거되면서 바이오차의 공극이 증가됨을 보고하였다. 또한 앞서 기술한 바와 같이 열분해 과정에서 방출된 물 분자 가 공극의 형성을 증대시키면서 이와 같은 관찰결과가 나타났 을 것으로 판단된다(Chan과 $\mathrm{Xu}, 2009)$.

$\mathrm{PM}, \mathrm{PBC} 300, \mathrm{PBC} 700$ 의 작용기 분석 결과 열분해 온도가 상승함에 따라 스펙트럼 상에서 작용기 peak가 매끄럽고 완만 해지는 것으로 관찰되었다(Fig. 2). 이는 열분해 시 고온에 의 한 작용기들의 감소에 기인한 결과로 판단된다( $\mathrm{Lim}$ 등, 2014). Coates (2000)에 방법에 준해 스펙트럼 상의 peak들을 해석한 결과 $\mathrm{PM}, \mathrm{PBC} 300$ 의 경우 2923 과 $2854 \mathrm{~cm}^{-1}$ 부근의 지방족 (aliphatic) $\mathrm{C}-\mathrm{H}$ peak, $1650 \mathrm{~cm}^{-1}$ 의 amide $\mathrm{N}-\mathrm{C}=\mathrm{O}$ peak가 관 찰되었으나 $\mathrm{PBC} 700$ 에서는 해당 그룹이 관찰되지 않았다. 한편, $\mathrm{PM}, \mathrm{PBC} 300, \mathrm{PBC} 700$ 모두 $1596 \mathrm{~cm}^{-1}$ 에서 방향족(aromatic) $\mathrm{C}=\mathrm{C}$ peak, $1410 \mathrm{~cm}^{-1}$ 에서 $\mathrm{C}-\mathrm{H}$ peak가 관찰되었다. 특히, 990$1100 \mathrm{~cm}^{-1}$ 부근의 phosphate ion peak, $873 \mathrm{~cm}^{-1}$ 의 aromatic $\mathrm{C}-\mathrm{H}$ peak가 $\mathrm{PM}, \mathrm{PBC} 300, \mathrm{PBC} 700$ 에서 모두 관찰되었다. 흡수 스펙트럼 내 aliphatic $\mathrm{C}-\mathrm{H}$, amide $\mathrm{N}-\mathrm{C}=\mathrm{O}$ 은 열분해 온도 상승 과 함께 점차 peak가 감소하여 $\mathrm{PBC} 700$ 에서는 존재하지 않았 


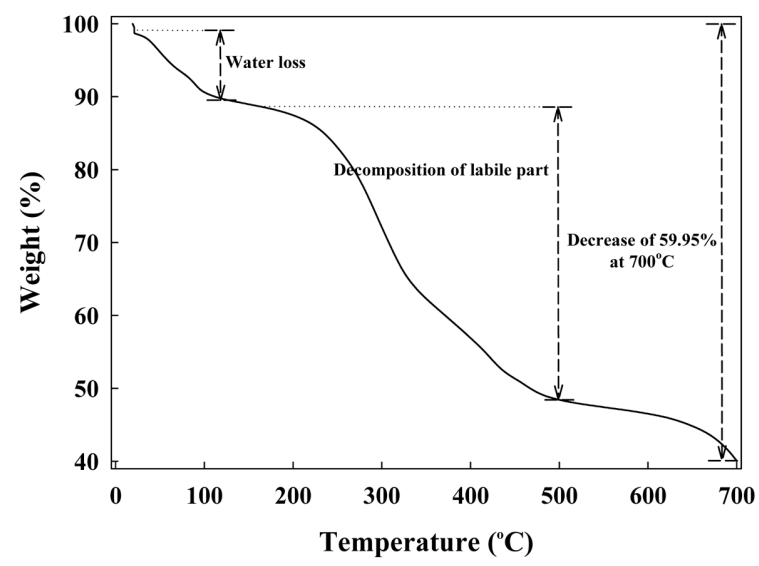

Fig. 3 Thermogravimetric analysis (TGA) of poultry manure (PM).

는데 이를 통해 휘발성의 작용기들은 감소하고 바이오차의 방 향성이 증대되는 것으로 판단되었다(Ahmad 등, 2012b).

바이오차 생산과정에서 열분해에 의한 $\mathrm{PM}$ 의 열적 안정성 평 가를 위한 열중량 분석결과는 Fig. 3과 같다. 분석 결과, 약 $100^{\circ} \mathrm{C}$ 부근과, 약 $200-500^{\circ} \mathrm{C}$ 사이에서 상대적으로 급격한 중 량의 감소가 나타났는데 이는 각각 수분의 증발과 유기물질의 분해·휘발에 의한 감소 효과인 것으로 판단되었다. 한편, $500^{\circ} \mathrm{C}$ 이후에는 중량이 서서히 감소하면서 $\mathrm{PBC} 700$ 생산을 위한 온도 인 $700^{\circ} \mathrm{C}$ 에서는 전체 중량의 약 $60 \%$ 가 감소하는 것으로 나타 났다.

$\mathrm{PM}, \mathrm{PBC300,} \mathrm{PBC700}$ 처리 후 토양의 화학적 특성변화. $\mathrm{PM}$, $\mathrm{PBC} 300, \mathrm{PBC} 700$ 처리 후 토양의 화학적 특성변화를 분석한 결과는 Table 3 과 같다. 토양의 $\mathrm{pH}$ 는 무처리구의 경우 6.94 였 으며 PM 처리구는 7.51까지 증가하였다(Table 3). 이와 유사하 게 Usman 등(2013)은 우리나라 농경지 토양에 계분을 $1 \mathrm{wt} \%$ 처리하는 연구에서 무처리구 토양의 $\mathrm{pH}$ 는 6.43 였으나 계분 처 리구의 $\mathrm{pH}$ 는 7.12 까지 상승함을 보고하였으며 이는 가축분 자 체의 알칼리적 특성과 계분과 같은 유기물질에 함유된 질소가 무기화(mineralization)되면서 발생하는 $\mathrm{NH}_{3}$ 에 의한 영향이라고
하였다(Ortiz Escobar와 Hue, 2008). 또한 $\mathrm{PBC} 300, \mathrm{PBC} 700$ 처리구 토양의 $\mathrm{pH}$ 는 각각 $7.24,7.88$ 까지 증가하는 것으로 나 타났다. 이와 유사하게 $\mathrm{Ahmad}$ 등 $(2014 \mathrm{a})$ 과 $400^{\circ} \mathrm{C}$ 에서 생산한 oak wood바이오차를 $5 \mathrm{wt} \%$ 수준으로 토양에 처리하였을 때 무 처리구의 $\mathrm{pH}$ (약 6.2)와 비교하여 $\mathrm{pH} 1$ 이상 상승(약 7.3)함을 보고하였으며, Almaroai 등(2014a)도 이와 동일한 바이오차를 5 $\mathrm{wt} \%$ 로 토양에 처리하였을 때 토양의 $\mathrm{pH}$ 가 상승함을 보고하였 고 이는 처리된 바이오차의 알칼리성(alkalinity)에 기인한다고 하였다. 한편, 토양의 $\mathrm{EC}$ 는 무처리구의 경우 $0.69 \mathrm{dS} / \mathrm{m}$ 였으며, $\mathrm{PM}, \mathrm{PBC} 300, \mathrm{PBC} 700$ 처리구에서는 각각 $3.69,5.42,3.27$ $\mathrm{dS} / \mathrm{m}$ 까지 증가하였다(Table 3). 이는 $\mathrm{PM}, \mathrm{PBC} 300, \mathrm{PBC} 700$ 에 함유된 무기 염류에 의한 것으로 판단된다(Table 2).

$\mathrm{PM}, \mathrm{PBC} 300, \mathrm{PBC} 700$ 처리 후 토양의 유기물과 총 질소 함량은 무처리구와 비교하여 유의한 수준으로 증가하였다(Table 3). 먼저 유기물 함량은 무처리구가 $29.46 \mathrm{~g} / \mathrm{kg}$ 였으며 PM, $\mathrm{PBC} 300, \mathrm{PBC} 700$ 처리구는 각각 33.91-51.89, 35.61-53.86, $34.22-42.50 \mathrm{~g} / \mathrm{kg}$ 까지 증가하였다. 총 질소 함량은 무처리구가

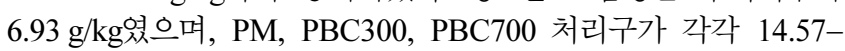
$36.90,18.33-54.23,14.13-32.70 \mathrm{~g} / \mathrm{kg}$ 까지 증가하였다. 유기물과 총 질소함량은 $\mathrm{PM}, \mathrm{PBC} 300$ 처리구 사이에는 서로 유의한 차 이가 없었으나 $\mathrm{PBC} 700$ 처리구의 경우 $\mathrm{PM}, \mathrm{PBC} 300$ 처리구에 비해 유의한 수준으로 낮아졌다. 이는 고온의 열분해 $\left(700^{\circ} \mathrm{C}\right)$ 를 통해 질소를 함유한 휘발성 유기물이 손실된 $\mathrm{PBC} 700$ 이 토양에 처리되면서 나타난 결과로 판단된다(Chan과 $\mathrm{Xu}, 2009)$.

토양의 유효인산 함량은 $\mathrm{PM}, \mathrm{PBC} 300, \mathrm{PBC} 700$ 처리구에서 모두 유의한 수준으로 증가하였는데(Table 3), 무처리구가 $371.00 \mathrm{mg} / \mathrm{kg}$ 였으며 $\mathrm{PM}, \mathrm{PBC} 300, \mathrm{PBC} 700$ 처리구가 각각 $577.00-1250.00,743.33-1980.33,613.00-1368.33 \mathrm{~g} / \mathrm{kg}$ 까지 증 가하였다. 이 중에서도 $\mathrm{PBC} 300$ 처리구의 유효인산의 함량이 가 장 크게 증가하였다. 인의 경우 열분해 온도가 상승함에 따라 총 인(Total P)의 함량은 증가할 수 있으나 유효태 인(Available $\mathrm{P})$ 의 농도는 감소하게 되는데(Chan과 $\mathrm{Xu}, 2009)$, 이와 유사하 게 본 연구 결과도 $\mathrm{PBC} 700$ 에 비해 상대적으로 낮은 온도에서 생산된 $\mathrm{PBC} 300$ 이 처리된 처리구에서 유효인산의 함량이 가장 높은 것으로 판단된다.

토양의 치환성 칼슘의 함량은 무처리구가 $10.48 \mathrm{cmol}_{(+)} / \mathrm{kg}$ 였

Table 3 Chemical properties in the control soil and treated soil. Same letters in the same column are not significantly different using Tukey's HSD test $(p<0.05, \mathrm{n}=3)$

\begin{tabular}{|c|c|c|c|c|c|c|c|c|c|}
\hline \multirow{2}{*}{\multicolumn{2}{|c|}{ Treatments }} & \multirow{3}{*}{$\begin{array}{l}\mathrm{pH} \\
1: 5\end{array}$} & \multirow{3}{*}{$\begin{array}{c}\text { EC } \\
(1: 5) \\
d S / m\end{array}$} & \multirow{2}{*}{$\mathrm{OM}$} & \multirow{2}{*}{ T-N } & \multirow{2}{*}{ Avail. $\mathrm{P}_{2} \mathrm{O}_{5}$} & \multicolumn{3}{|c|}{ Exchangeable cations } \\
\hline & & & & & & & $\mathrm{Ca}$ & $\mathrm{K}$ & $\mathrm{Mg}$ \\
\hline & & & & \multicolumn{2}{|c|}{------ g/kg ------ } & $\mathrm{mg} / \mathrm{kg}$ & \multicolumn{3}{|c|}{----- $\mathrm{cmol}_{(+)} / \mathrm{kg}$----- } \\
\hline \multicolumn{2}{|c|}{ Control } & $6.94 \mathrm{f}$ & $0.69 \mathrm{f}$ & $29.46 \mathrm{~d}$ & $6.93 \mathrm{c}$ & $371.00 \mathrm{~g}$ & $10.48 \mathrm{a}$ & $0.40 \mathrm{~g}$ & $1.87 \mathrm{e}$ \\
\hline \multirow{3}{*}{$\mathrm{PM}^{\mathrm{a}}$} & $2.5 \%$ & 7.06ef & $1.46 \mathrm{e}$ & $33.91 \mathrm{c}$ & $14.57 \mathrm{bc}$ & $577.00 \mathrm{f}$ & $10.78 \mathrm{a}$ & $0.94 f$ & $2.15 \mathrm{de}$ \\
\hline & $5.0 \%$ & $7.46 \mathrm{~b}$ & $2.09 \mathrm{~d}$ & $37.67 \mathrm{c}$ & $20.90 \mathrm{~b}$ & $924.00 \mathrm{~d}$ & $11.04 \mathrm{a}$ & $1.59 \mathrm{e}$ & $2.61 \mathrm{bcd}$ \\
\hline & $10.0 \%$ & $7.51 b$ & $3.69 \mathrm{~b}$ & $51.89 \mathrm{a}$ & $36.90 \mathrm{a}$ & $1250.00 \mathrm{c}$ & $11.57 \mathrm{a}$ & $2.89 \mathrm{c}$ & $2.88 \mathrm{bc}$ \\
\hline \multirow{3}{*}{$\mathrm{PBC} 300^{\mathrm{b}}$} & $2.5 \%$ & $7.02 \mathrm{ef}$ & $1.83 \mathrm{de}$ & $35.61 \mathrm{c}$ & $18.33 \mathrm{bc}$ & $743.33 \mathrm{e}$ & $10.37 \mathrm{a}$ & $0.97 \mathrm{f}$ & $2.29 \mathrm{cde}$ \\
\hline & $5.0 \%$ & $7.14 \mathrm{de}$ & $3.05 \mathrm{c}$ & $42.89 \mathrm{~b}$ & $30.50 \mathrm{~b}$ & $1007.00 \mathrm{~d}$ & $11.09 \mathrm{a}$ & $1.70 \mathrm{e}$ & $2.63 \mathrm{bcd}$ \\
\hline & $10.0 \%$ & $7.24 \mathrm{~cd}$ & $5.42 \mathrm{a}$ & $53.86 \mathrm{a}$ & $54.23 \mathrm{a}$ & $1980.33 \mathrm{a}$ & $11.41 \mathrm{a}$ & $3.42 b$ & $3.04 \mathrm{~b}$ \\
\hline \multirow{3}{*}{$\mathrm{PBC} 700^{\mathrm{c}}$} & $2.5 \%$ & $7.30 \mathrm{c}$ & $1.41 \mathrm{e}$ & $34.22 \mathrm{c}$ & $14.13 \mathrm{c}$ & $613.00 \mathrm{f}$ & $7.85 b$ & $1.07 \mathrm{f}$ & $1.81 \mathrm{e}$ \\
\hline & $5.0 \%$ & $7.55 b$ & $2.12 \mathrm{~d}$ & $37.00 \mathrm{c}$ & $21.20 \mathrm{c}$ & $759.33 \mathrm{e}$ & $11.16 \mathrm{a}$ & $2.19 \mathrm{~d}$ & $3.11 \mathrm{~b}$ \\
\hline & $10.0 \%$ & $7.88 \mathrm{a}$ & $3.27 \mathrm{be}$ & $42.50 \mathrm{~b}$ & $32.70 \mathrm{bc}$ & $1368.33 b$ & $10.45 \mathrm{a}$ & $4.17 \mathrm{a}$ & $4.06 \mathrm{a}$ \\
\hline
\end{tabular}

${ }^{a}$ Poultry manure; ${ }^{b}$ Poultry manure biochar pyrolyzed at $300^{\circ} \mathrm{C} ;{ }^{\circ}$ Poultry manure biochar pyrolyzed at $700^{\circ} \mathrm{C}$. 


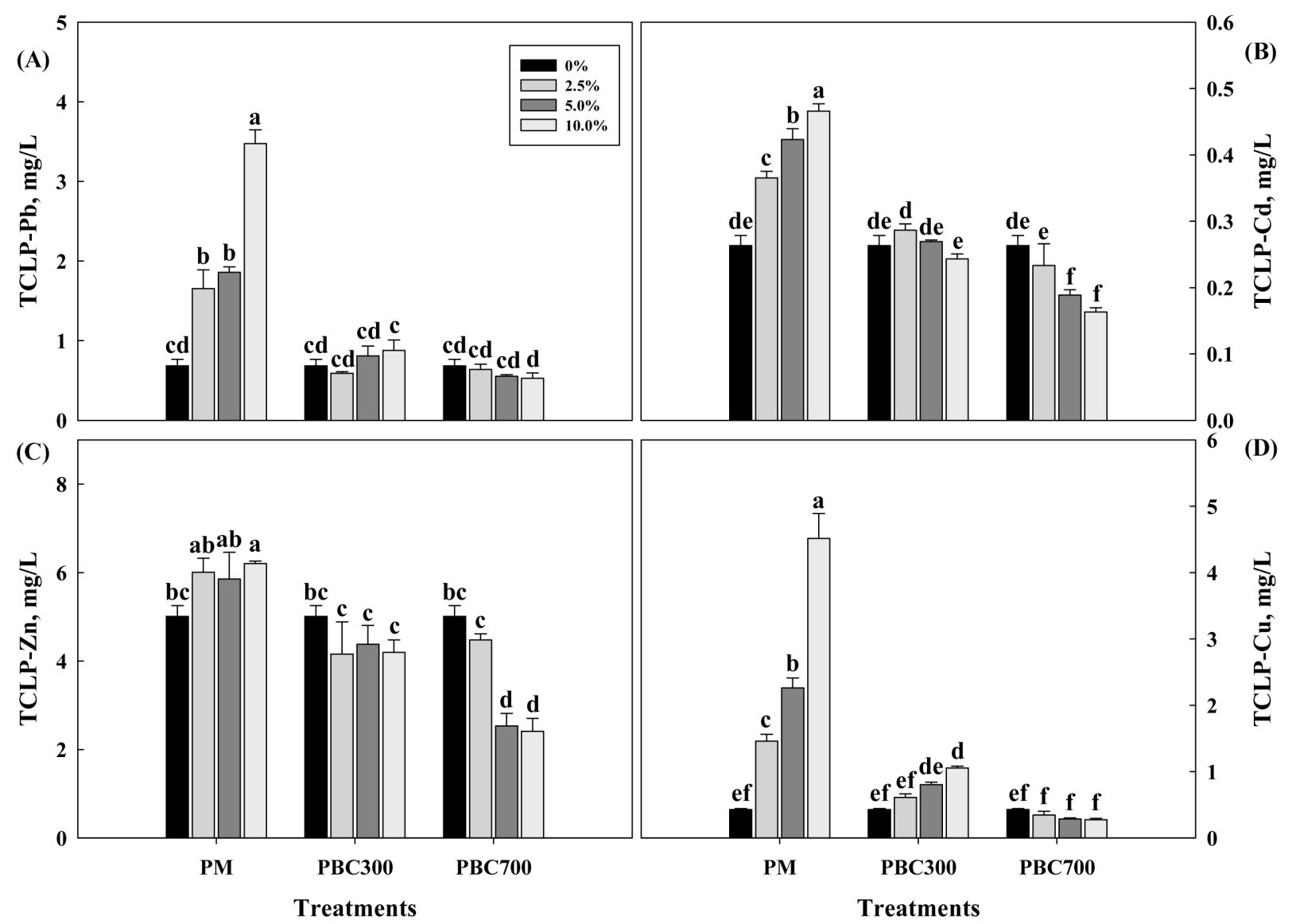

Fig. 4 Concentrations of TCLP extractable (A) $\mathrm{Pb},(\mathrm{B}) \mathrm{Cd},(\mathrm{C}) \mathrm{Zn}$ and (D) $\mathrm{Cu}$ in soils treated with poultry manure (PM), poultry manure biochar pyrolyzed at $300^{\circ} \mathrm{C}(\mathrm{PBC} 300)$ and poultry manure biochar pyrolyzed at $700^{\circ} \mathrm{C}(\mathrm{PBC} 700)$ at $2.5,5$ and $10 \%$ application rates. Same letters above bars are not significantly different using Tukey's HSD test $(p<0.05, \mathrm{n}=3)$.

으며 $\mathrm{PM}, \mathrm{PBC} 300, \mathrm{PBC} 700$ 처리구는 통계적으로 유의한 차이 가 없었다(Table 3$)$. 치환성 칼륨의 함량은 무처리구가 0.40 $\mathrm{cmol}_{(+)} / \mathrm{kg}$ 였으며 $\mathrm{PM}, \mathrm{PBC} 300, \mathrm{PBC} 700$ 처리구는 각각 2.89 , $3.42,4.17 \mathrm{cmol}_{(+)} / \mathrm{kg}$ 까지 유의한 수준으로 증가하였다. 치환성

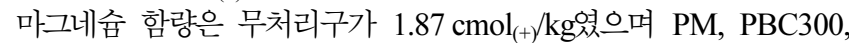
$\mathrm{PBC} 700$ 처리구는 각각 $2.88,3.04,4.06 \mathrm{cmol}_{(+)} / \mathrm{kg}$ 까지 유의한 수준으로 증가하였다. Cantrell 등(2012)은 가축분 바이오차가 열분해 $\left(350,700^{\circ} \mathrm{C}\right)$ 에 의해 무기양분 $(\mathrm{Ca}, \mathrm{K}, \mathrm{Mg}$ 등)이 농축되 어 그 함량이 원재료에 비해 증가된다고 하였다. 본 연구 결과 도 열분해를 통해 농축된 무기양분이 토양에 처리됨에 따라 나 타난 결과로 판단된다.

TCLP용출시험 결과. 항온배양 후 $\mathrm{PM}, \mathrm{PBC} 300, \mathrm{PBC} 700$ 처리 에 따른 토양 내 중금속의 용출정도를 $\mathrm{TCLP}$ 를 통해 알아본 결 과는 Fig. 4와 같다.

납의 경우 무처리구의 농도는 $0.68 \mathrm{mg} / \mathrm{L}$ 였으며, $\mathrm{PM}, \mathrm{PBC} 300$, $\mathrm{PBC} 700$ 처리구는 각각 $1.65-3.47,0.59-0.88,0.64-0.53 \mathrm{mg} / \mathrm{L}$ 로 나타나 $\mathrm{PBC} 700$ 을 제외한 모든 처리구에서 납의 농도가 증 가하였다(Fig. 4A). 카드뮴의 경우 무처리구의 농도는 $0.26 \mathrm{mg}$ / $\mathrm{L}$ 였으며, $\mathrm{PM}, \mathrm{PBC} 300, \mathrm{PBC} 700$ 처리구는 각각 0.37-0.47, $0.29-0.24,0.23-0.16 \mathrm{mg} / \mathrm{L}$ 로 나타나 $\mathrm{PBC} 300 \quad 10.0 \%$ 및 $\mathrm{PBC} 700$ 처리구를 제외한 모든 처리구에서 카드뮴의 농도가 증가하였다 (Fig. 4B). 아연의 경우 무처리구의 농도는 $5.01 \mathrm{mg} / \mathrm{L}$ 였으며,
$\mathrm{PM}, \mathrm{PBC} 300, \mathrm{PBC} 700$ 처리구는 각각 6.01-6.20, 4.16-4.20, 4.48-2.41 mg/L로 나타나 PM 처리구에서만 유일하게 아연의 농 도가 증가하였다(Fig. $4 \mathrm{C})$. 구리의 경우 무처리구의 농도는 $0.43 \mathrm{mg} / \mathrm{L}$ 였으며, $\mathrm{PM}, \mathrm{PBC} 300, \mathrm{PBC} 700$ 처리구는 각각 $1.46-$ $4.51,0.61-1.06,0.34-0.28 \mathrm{mg} / \mathrm{L}$ 로 나타나 $\mathrm{PBC} 700$ 을 제외한 모든 처리구에서 구리의 농도가 증가하였다(Fig. 4D).

$\mathrm{PM}$ 처리구의 경우 모든 조사대상 중금속의 농도가 증가하였 는데 살펴보면, 납이 약 $142-408 \%$, 카드뮴이 약 $39-77 \%$, 아 연이 약 20-24\%, 구리가 약 241-955\% 수준으로 증가하여 가 용화(mobilization)되는 것으로 나타났다(Table 4). 일반적으로 가 축분 등의 유기성 토양 처리제는 토양의 $\mathrm{DOC}$ 와 같은 용해성 유기물(DOM, dissolved organic matter)을 증대시키는데(Usman 등, 2013), 본 연구결과 각 $10 \mathrm{wt} \%$ 처리구별 토양의 $\mathrm{DOC}$ 함 량은 $\mathrm{PM}$ 처리구 $(127.08 \mathrm{mg} / \mathrm{L})>\mathrm{PBC} 300$ 처리구 $(25.73 \mathrm{mg} / \mathrm{L})>$ $\mathrm{PBC} 700$ 처리구 $(9.63 \mathrm{mg} / \mathrm{L})$ 무처리구 $(9.03 \mathrm{mg} / \mathrm{L})$ 의 순으로 나타 났다. 특히, DOC 함량과 TCLP 용출성 중금속의 농도는 매우 높은 수준의 정의 상관관계를 나타내었으며 토양의 $\mathrm{pH}$ 를 비롯 한 다른 항목들과는 연관성이 없는 것으로 나타났다(Table 5). 그러므로 $\mathrm{PM}$ 처리구에서 나타난 중금속 용출농도 증가는 계분 처리에 의해 증가된 토양 내 $\mathrm{DOC}$ 함량과 관련이 있는 것으로 판단되었다. 토양의 $\mathrm{pH}$ 가 중성이나 알칼리성과 같이 상대적으 로 높은 조건일 때, DOM이 함유한 작용기(hydroxyl group, 
Table 4 Percentage stabilized metals $(\mathrm{Pb}, \mathrm{Cd}, \mathrm{Zn}$ and $\mathrm{Cu})$ in soils treated with poultry manure $(\mathrm{PM})$, poultry manure biochar pyrolyzed at $300^{\circ} \mathrm{C}$ (PBC300) and poultry manure biochar pyrolyzed at $700^{\circ} \mathrm{C}(\mathrm{PBC} 700)$ at 2.5, 5 and $10 \%$ application rates. Negative numbers indicate the $\%$ mobilized metals.

\begin{tabular}{cccccc}
\hline \multirow{2}{*}{ Treatments } & $\mathrm{Pb}$ & $\mathrm{Cd}$ & $\mathrm{Zn}$ & $\mathrm{Cu}$ \\
\cline { 2 - 6 } & & \multicolumn{4}{c}{ Stabilization rate $(\%)$} \\
\hline \multirow{2}{*}{$\mathrm{PM}$} & $2.5 \%$ & -141.91 & -38.73 & -19.86 & -241.28 \\
& $5.0 \%$ & -171.54 & -60.76 & -16.94 & -428.82 \\
& $10.0 \%$ & -407.99 & -76.96 & -23.80 & -954.67 \\
\hline \multirow{2}{*}{ PBC300 } & $2.5 \%$ & 13.84 & -8.86 & 17.03 & -42.83 \\
& $5.0 \%$ & -18.23 & -2.28 & 12.59 & -87.69 \\
& $10.0 \%$ & -28.46 & 7.59 & 16.21 & -146.57 \\
\hline \multirow{2}{*}{ PBC700 } & $2.5 \%$ & 6.82 & 11.39 & 10.67 & 19.47 \\
& $5.0 \%$ & 19.30 & 28.35 & 49.48 & 33.33 \\
& $10.0 \%$ & 22.71 & 37.97 & 51.86 & 35.51 \\
\hline
\end{tabular}

carboxyl group)의 이온화 반응이 용이해져 중금속 이온과 결합 할 수 있는 음전하를 증가시키고, 이렇게 형성된 용해성 DOM중금속 복합체의 산소, 질소 함유 작용기들이 해리되면서 음전 하가 증가된다(Wong 등, 2007). 이 경우 동일하게 음전하를 띤 토양과 반발하면서 중금속의 토양 흡착이 감소하고 이동성이 증 대될 수 있다(Zhou와 Wong, 2001; Wong 등, 2007). 특히, Wong 등(2007)은 토양의 pH 5-8 조건일 때 DOM에 의하여 카드뮴과 아연의 토양 흡착이 감소하며, $\mathrm{pH} 7-7.5$ 인 경우에 흡 착 감소가 최대에 도달함을 보고하였다. 더욱이 $\mathrm{PM}$ 처리구의 토 양 $\mathrm{pH}$ 는 7.06-7.51로 나타나 이러한 내용에 잘 부합하였다 (Table 3). 또한 Pérez-Esteban 등(2014)은 양과 말의 분(manure) 이 $1: 1$ (v:v)로 혼합된 축분을 토양에 적용하는 연구를 통해 높 은 $\mathrm{pH}$ 에서 토양유기탄소(SOC, soil organic carbon)가 구리와 soluble complex를 형성하면서 토양의 구리 흡착이 감소되어 soluble $\mathrm{Cu}$ 가 증가한다고 하여 본 연구 결과와 유사하다. 한편, 조사대상 중금속 중 구리의 경우 가장 큰 가용화율을 나타내었 는데(Table 4), 이는 구리가 타 중금속에 비해 DOM 등의 유기 물질과 화학적 친화성(affinity)이 높아 복합체를 형성하면서 가 용화되는 정도가 큰 것에 기인한 결과로 판단된다(Adriano, 2001; Zhou와 Wong, 2001).

$\mathrm{PBC} 700$ 처리구의 경우 $\mathrm{PM}$ 처리구와 달리 납이 약 7-23\%, 카드뮴이 약 $11-38 \%$, 아연이 약 $11-52 \%$, 구리가 약 $19-36 \%$ 수준으로 감소하여 안정화되는 것으로 나타났다(Table 4). $\mathrm{PBC} 700$ 처리구의 $\mathrm{DOC}$ 함량은 무처리구와 거의 동일한 수준 으로써 용출되는 중금속의 감소는 $\mathrm{pH}$ 등의 다른 인자가 관련 된 것으로 판단되었다. 토양의 $\mathrm{pH}$ 는 중금속의 용해도와 생물유 효도를 제어하는 인자이며(Brallier 등, 1996), $\mathrm{pH}$ 가 상승하는 경 우 토양 표면의 음전하가 증대되어 양이온성 중금속의 흡착이 증대된다(Zhao와 Masaihiko, 2007). 이와 함께 토양의 $\mathrm{pH}$ 가 알 칼리 조건으로 바뀌면 중금속 양이온은 수산화물을 형성하게 되 어 안정화된다(Zhao와 Masaihiko, 2007; Ok 등, 2010). 본 연 구결과도 알칼리성인 $\mathrm{PBC} 700(\mathrm{pH} 10.70)$ 이 토양에 처리되면서 $\mathrm{PBC} 700$ 처리구의 $\mathrm{pH}$ 가 7.88까지 상승하였는데(Table 3), 이에 따라 양이온성의 중금속인 납, 카드뮴, 아연, 구리가 안정화되 어 용출농도가 감소한 것으로 판단된다. 한편, $\mathrm{CaO}$ 등(2011)은 유효태 인을 다량 함유한 dairy manure를 $450^{\circ} \mathrm{C}$ 에서 바이오차
Table 5 Correlation coefficients between TCLP-extractable metal concentrations and soil properties

\begin{tabular}{lcccc}
\hline \multicolumn{1}{c}{ Variables } & $\mathrm{Cd}^{\mathrm{a}}$ & $\mathrm{Cu}^{\mathrm{a}}$ & $\mathrm{Pb}^{\mathrm{a}}$ & $\mathrm{Zn}^{\mathrm{a}}$ \\
\hline $\mathrm{DOC}^{\mathrm{b}}$ & $\mathbf{0 . 9 4 4 4}^{* * *}$ & $\mathbf{0 . 9 9 5 4 * * *}$ & $\mathbf{0 . 9 9 4 9 * * *}$ & $\mathbf{0 . 7 3 4 3} * *$ \\
$\mathrm{pH}$ & -0.1325 & 0.1274 & 0.1360 & -0.5017 \\
$\mathrm{EC}^{\mathrm{c}}$ & 0.0537 & 0.2669 & 0.1964 & -0.1331 \\
$\mathrm{OM}^{\mathrm{d}}$ & 0.3478 & 0.5256 & 0.4736 & 0.1146 \\
$\mathrm{~T}^{\mathrm{e}}$ & 0.4635 & $0.5993 *$ & 0.5384 & 0.2814 \\
Available $\mathrm{P}_{2} \mathrm{O}_{5}$ & -0.0994 & 0.1197 & 0.0526 & -0.2797 \\
Exchangeable Ca & 0.4122 & 0.4110 & 0.3949 & 0.3059 \\
Exchangeable $\mathrm{K}$ & -0.1986 & 0.0890 & 0.0535 & -0.5305 \\
Exchangeable $\mathrm{Mg}$ & -0.3546 & -0.0905 & -0.1038 & $\mathbf{- 0 . 6 8 9 1}$ \\
\hline
\end{tabular}

Correlation significant levels: ${ }^{*} p<0.05,{ }^{* *} p<0.01,{ }^{* * *} p<0.001$.

${ }^{a}$ TCLP (Toxicity characteristics leaching procedure) extractable metals; bissolved organic carbon; 'Electrical conductivity; ${ }^{\mathrm{d}}$ Organic matter; ${ }^{\mathrm{e}} \mathrm{To}-$ tal nitrogen.

로 생산한 후 사격장 토양 내 납을 정화하는 연구에서 불용성 의 hydroxypyromorphite $\left[\mathrm{Pb}_{5}\left(\mathrm{PO}_{4}\right)_{3}(\mathrm{OH})\right]$ 형성이 토양으로부터 용출되는 납의 농도 감소에 대한 주요 메커니즘임을 보고하였 다. 이와 유사하게 본 연구결과에서도 $\mathrm{PBC} 700$ 처리에 의하여 토양 내 유효인산의 함량이 급격하게 증가하였는데(Table 3), 이 를 통해 납 농도 감소의 원인이 hydroxypyromorphite 등의 형 성과도 관련 가능성이 있는 것으로 판단되었다.

한편, $\mathrm{PBC} 300$ 처리구의 중금속 용출농도는 $\mathrm{PM}$ 처리구와 $\mathrm{PBC} 700$ 처리구의 결과의 중간에 해당하는 경향이 나타났다(Fig. 4). 아연의 경우에는 $\mathrm{PBC} 300$ 처리량과 상관없이 용출농도가 감 소(약 13-17\%)하여 안정화되었으나, 납의 경우에 용출농도가 증가(약 18-28\%) 또는 감소(약 $14 \%)$, 카드뭄의 경우에도 용출 농도가 증가(약 2-9\%) 또는 감소(약 $8 \%$ )하는 것으로 나타났다. 특히, 구리의 경우 $\mathrm{PBC} 300$ 처리량 증가에 따라 용출농도가 증 가(약 43-147\%)하여 가용화되는 것으로 나타났다(Table 4).

열역학 모델링 결과. $\mathrm{PM}, \mathrm{PBC} 300, \mathrm{PBC} 700$ 처리에 따른 오염 토양 내 화학종 형성 예측을 위해 visual MINTEQ으로 열역학 모델링을 실시한 결과는 Table 6과 같다. 연구결과 과포화상태 $(\mathrm{SI}>0)$ 로서 침전이 예상되는 납 화학종으로는 인 함유물질인 chloropyromorphite $\left[\mathrm{Pb}_{5}\left(\mathrm{PO}_{4}\right)_{3} \mathrm{Cl}\right]$, hydroxypyromorphite, $\mathrm{Pb}_{3}\left(\mathrm{PO}_{4}\right)_{2}$, $\mathrm{PbHPO}_{4}$, plumbogummite $\left[\mathrm{PbAl}_{3}\left(\mathrm{PO}_{4}\right)_{2}(\mathrm{OH})_{5} \cdot \mathrm{H}_{2} \mathrm{O}\right]$, tsumebite $\left[\mathrm{Pb}_{2} \mathrm{Cu}\left(\mathrm{PO}_{4}\right)\left(\mathrm{SO}_{4}\right)(\mathrm{OH})\right]$ 가 예측되었고, 수산화물인 $\mathrm{Pb}(\mathrm{OH})_{2}$ 도 예측되었다. 구리 화학종의 경우에도 brochantite $\left[\mathrm{Cu}_{4}\left(\mathrm{SO}_{4}\right)(\mathrm{OH})_{6}\right]$ 와 $\mathrm{Cu}_{3}\left(\mathrm{PO}_{4}\right)_{2}$ 등 주로 인과 황을 함유한 물질들과 수산화물인 $\mathrm{Cu}(\mathrm{OH})_{2}$ 등이 예측되었다. 아연의 화학종으로는 $\mathrm{Zn}_{3}\left(\mathrm{PO}_{4}\right)_{2} \cdot 4 \mathrm{H}_{2} \mathrm{O}$ 만 예측되었다. 이러한 결과는 $\mathrm{PM}, \mathrm{PBC} 300, \mathrm{PBC} 700$ 이 함유 한 황과 인에 의한 결과로 판단된다. 한편, 카드뮴의 화학종은 예측되지 않았으며 이는 토양 중 카드뮴이 납, 아연, 구리에 비 해 저농도인 것에 기인한 것으로 판단되었다(Table 1). 침전이 예상되는 화학종들의 SI값은 plumbogummite, cupric ferrite를 제외하면 $\mathrm{PBC} 700$ 처리구>무처리구>PBC300 처리구>PM 처리 구의 순서로 나타나 $\mathrm{PBC} 700$ 처리구가 가장 큰 것으로 나타났 으며 이를 통해 예상되는 화학종의 침전형성이 PBC700 처리구 에서 가장 활발할 것으로 판단되었다. 이는 TCLP 용출성 중금 속의 안정화가 $\mathrm{PBC} 700$ 처리구에서 가장 높은 것을 나타내는 결과(Table 4)로써 예상되는 화학종의 침전물 형성을 통해 중금 속이 안정화되는 것으로 판단되었다. 특히, 납 화학종으로 예상 
Table 6 Precipitation minerals in a water aqueous system of control soil and treated soils as predicted by the visual MINTEQ thermodynamic model

\begin{tabular}{|c|c|c|c|c|c|}
\hline \multirow{2}{*}{$\mathrm{Pb}$ containing minerals } & \multirow{2}{*}{ Chemical formula } & \multicolumn{4}{|c|}{ Saturation index (SI) } \\
\hline & & Control & $\mathrm{PM}^{\mathrm{a}}$ & $\mathrm{PBC} 300^{\mathrm{b}}$ & $\mathrm{PBC} 700^{\circ}$ \\
\hline Chloropyromorphite & $\mathrm{Pb}_{5}\left(\mathrm{PO}_{4}\right)_{3} \mathrm{Cl}$ & 17.98 & 1.58 & 8.81 & 20.44 \\
\hline Hydroxypyromorphite & $\mathrm{Pb}_{5}\left(\mathrm{PO}_{4}\right)_{3} \mathrm{OH}$ & 11.33 & -5.66 & 0.83 & 12.53 \\
\hline $\mathrm{Pb}_{3}\left(\mathrm{PO}_{4}\right)_{2}$ & $\mathrm{~Pb}_{3}\left(\mathrm{PO}_{4}\right)_{2}$ & 6.31 & -4.21 & 0.04 & 7.03 \\
\hline $\mathrm{PbHPO}_{4}$ & $\mathrm{PbHPO}_{4}$ & 0.83 & -3.22 & -1.21 & 1.07 \\
\hline $\mathrm{Pb}(\mathrm{OH})_{2}$ & $\mathrm{~Pb}(\mathrm{OH})_{2}$ & 0.58 & -1.83 & -1.62 & 0.82 \\
\hline Plumbogummite & $\mathrm{PbAl}_{3}\left(\mathrm{PO}_{4}\right)_{2}(\mathrm{OH})_{5} \cdot \mathrm{H}_{2} \mathrm{O}$ & 13.36 & 0.68 & -0.12 & 8.92 \\
\hline Tsumebite & $\mathrm{Pb}_{2} \mathrm{Cu}\left(\mathrm{PO}_{4}\right)\left(\mathrm{SO}_{4}\right)(\mathrm{OH})$ & 4.87 & -5.42 & -1.47 & 5.55 \\
\hline \multicolumn{6}{|l|}{$\mathrm{Cu}$ containing minerals } \\
\hline Antlerite & $\mathrm{Cu}_{3}\left(\mathrm{SO}_{4}\right)(\mathrm{OH})_{4}$ & 0.25 & -12.01 & -5.34 & 1.29 \\
\hline Atacamite & $\mathrm{Cu}_{2} \mathrm{Cl}(\mathrm{OH})_{3}$ & 0.30 & -6.76 & -2.58 & 1.96 \\
\hline Brochantite & $\mathrm{Cu}_{4}\left(\mathrm{SO}_{4}\right)(\mathrm{OH})_{6}$ & 3.14 & -12.94 & -4.55 & 4.38 \\
\hline $\mathrm{Cu}(\mathrm{OH})_{2}$ & $\mathrm{Cu}(\mathrm{OH})_{2}$ & 0.04 & -3.79 & -2.07 & 0.23 \\
\hline $\mathrm{Cu}_{3}\left(\mathrm{PO}_{4}\right)_{2}$ & $\mathrm{Cu}_{3}\left(\mathrm{PO}_{4}\right)_{2}$ & 1.44 & -13.33 & -4.58 & 2.02 \\
\hline $\mathrm{Cu}_{3}\left(\mathrm{PO}_{4}\right)_{2} \cdot 3 \mathrm{H}_{2} \mathrm{O}$ & $\mathrm{Cu}_{3}\left(\mathrm{PO}_{4}\right)_{2} \cdot 3 \mathrm{H}_{2} \mathrm{O}$ & -0.29 & -15.06 & -6.31 & 0.29 \\
\hline Tenorite & $\mathrm{CuO}$ & 0.84 & -2.99 & -1.27 & 1.03 \\
\hline Cupric Ferrite & $\mathrm{CuFe}_{2} \mathrm{O}_{4}$ & 21.81 & -25.47 & -24.62 & 14.39 \\
\hline Langite & $\mathrm{Cu}_{4}\left(\mathrm{SO}_{4}\right)(\mathrm{OH})_{6} \cdot 2 \mathrm{H}_{2} \mathrm{O}$ & 0.88 & -15.21 & -6.82 & 2.12 \\
\hline Tsumebite & $\mathrm{Pb}_{2} \mathrm{Cu}\left(\mathrm{PO}_{4}\right)\left(\mathrm{SO}_{4}\right)(\mathrm{OH})$ & 4.87 & -5.42 & -1.47 & 5.55 \\
\hline \multicolumn{6}{|l|}{$\mathrm{Zn}$ containing minerals } \\
\hline $\mathrm{Zn}_{3}\left(\mathrm{PO}_{4}\right)_{2} \cdot 4 \mathrm{H}_{2} \mathrm{O}$ & $\mathrm{Zn}_{3}\left(\mathrm{PO}_{4}\right)_{2} \cdot 4 \mathrm{H}_{2} \mathrm{O}$ & -0.23 & 0.27 & 0.27 & 0.80 \\
\hline
\end{tabular}

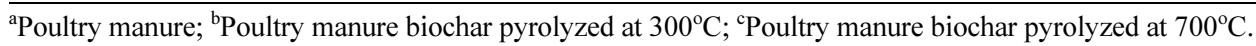

된 pyromorphite 유형의 광물들은 토양 내 납의 안정화를 위해 인산염 등 인 함유개량제를 처리하는 경우 형성되는 물질로써 매우 낮은 용해도를 보유하여 납-인산염광물들 중 가장 안정한 물질로 알려져 있다(Ryan 등, 2001; Kumpiene 등, 2008). 이 중 chloropyromorphite는 hydroxy-, bromo-, fluoro-pyromorphite 중 용해성이 가장 낮은 광물로(Ryan 등, 2001), $\mathrm{K}_{\mathrm{sp}}$ (solubility product) 값이 $10^{-84.4}$ 로 매우 낮아 화학적으로 안정하다고 알려 진 물질이다(Hashimoto 등 2009). 또한 hydroxypyromorphite의 $\mathrm{K}_{\mathrm{sp}}$ 값도 약 $10^{-78}$ 으로 매우 낮은 편이다(Cao 등, 2011). 그러 므로 중금속 용출시험 결과(Fig. 4, Table 4)와 모델링 결과 (Table 6)를 종합할 때, $\mathrm{PBC700}$ 처리구의 납 안정화는 $\mathrm{PBC} 700$ 이 함유한 인과 토양 내 납이 chloro- 및 hydroxy-pyromorphite 침전물을 형성하면서 나타난 결과로 판단된다.

SEM 및 elemental dot mapping 분석 결과. $\mathrm{PM}, \mathrm{PBC} 300$, $\mathrm{PBC} 700$ 처리에 따른 오염토양의 미세구조 및 elemental dot mapping을 통한 원소분포 조사 결과는 Fig. 5와 같다. 원소분 포 조사 결과, $\mathrm{PM}(\mathrm{Fig}$. 5A) 및 $\mathrm{PBC} 300$ 처리구(Fig. 5B)의 경 우에는 elemental dot map 상에서 규소 $(\mathrm{Si})$, 알루미늄 $(\mathrm{Al})$, 산소, 인 등이 관찰되었으며 납은 거의 관찰되지 않았다. 이와 달리 PBC700 처리구(Fig. 5C)에서는 dot map 상에서 규소, 알루미 늄, 산소, 인과 함께 납이 확인되었다. 특히 납이 분포하는 부 분에서 인의 분포가 확인되어 두 원소간의 연관성이 있는 것으 로 판단되었다(Moon등, 2013). 이는 열역학 모델링(Table 6)을 통해 예상된 chloropyromorphite, hydroxypyromorphite 등 인 함유 납 화학종의 침전물 형성을 뒷받침하는 결과이다. 이를 통 해 용출시험 결과(Fig. 4)에서 제시된 $\mathrm{PBC} 700$ 처리구의 납 농 도 감소는 $\mathrm{PBC} 700$ 이 함유한 인과 오염토양에 존재하는 납이 화학종(chloropyromorphite, hydroxypyromorphite 등)을 형성하
면서 나타난 결과로 판단된다. 한편, 구리와 아연의 경우 열역 학 모델링 결과에서 인 화학종의 형성이 예측되었으나 카드뮴 과 함께 elemental dot mapping을 통해 관찰되지 않았으며 이 는 본 연구에서 사용된 토양 중 카드뮴, 아연, 구리가 납에 비 해 상대적으로 저농도로 존재하고 있어 관찰되지 않은 것으로 판단된다.

연구결과를 종합하면, 오염토양에 대한 양분 증대 및 중금속 안정화를 위해 계분을 처리하는 경우 양분 증대 효과는 기대할 수 있으나 중금속 안정화 효과는 토양의 $\mathrm{pH}, \mathrm{DOC}$ 함량이 고 려되어야 하므로 그 사용이 매우 제한적일 수 있다. 그러므로 이를 보완하기 위해 본 연구결과에서 나타난 바와 같이 양분 증대 및 중금속의 안정화가 동시에 가능한 계분 바이오차의 토 양 처리가 매우 적절한 것으로 판단된다.

\section{초 록}

본 연구에서는 오염토양 내 중금속 안정화 효율 평가를 위해 계분 $(\mathrm{PM}), 300^{\circ} \mathrm{C}$ 에서 생산한 바이오차 $(\mathrm{PBC} 300), 700^{\circ} \mathrm{C}$ 에서 생 산한 바이오차(PBC700)를 $2.5,5.0,10.0 \mathrm{wt} \%$ 수준으로 토양에 처리하고 21 일 간 항온배양하였다. 항온배양 후 토양의 $\mathrm{pH}$ 는 $\mathrm{PM} 10.0 \mathrm{wt} \%, \mathrm{PBC} 30010.0 \mathrm{wt} \%, \mathrm{PBC} 70010 \mathrm{wt} \%$ 처리구 에서 각각 $7.51,7.24,7.88$ 로 나타나 무처리구 $(\mathrm{pH}$ 6.94)에 비해 유의적으로 증가하였는데 이는 $\mathrm{PM}, \mathrm{PBC} 300, \mathrm{PBC} 700$ 자체의 알칼리성에 기인한 결과로 판단되었다. 중금속의 TCLP 용출시 험 결과 PM 처리구의 경우 용출되는 납(142-408\% 증가), 카드 뮴(39-77\% 증가), 아연(20-24\% 증가), 구리(241-955\% 증가)의 농도가 모두 증가하였으며, 이는 PM 처리 시 급격하게 증가된 
(A)
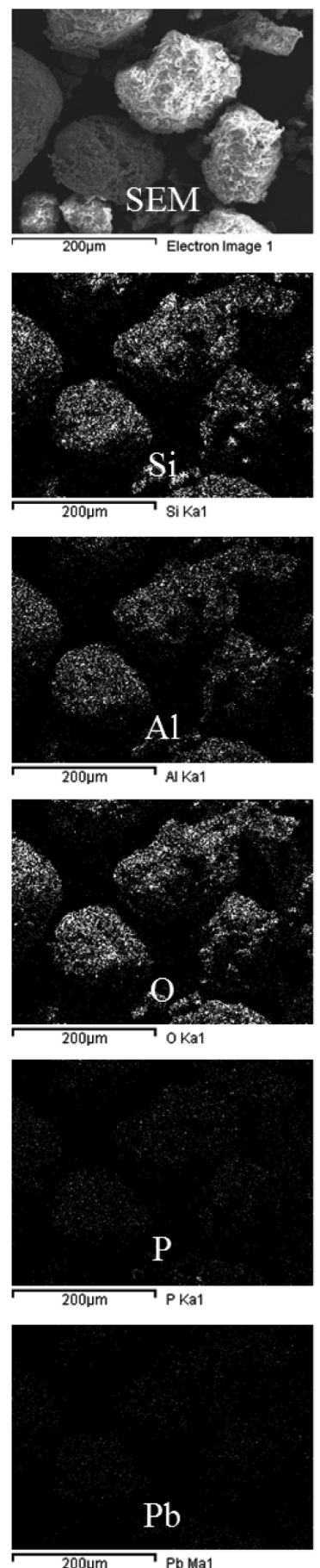

(B)
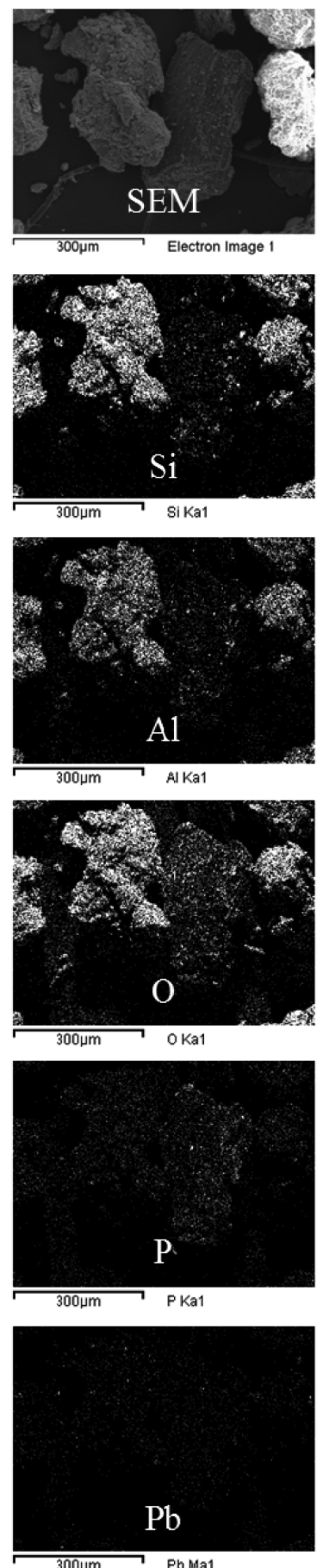

(C)
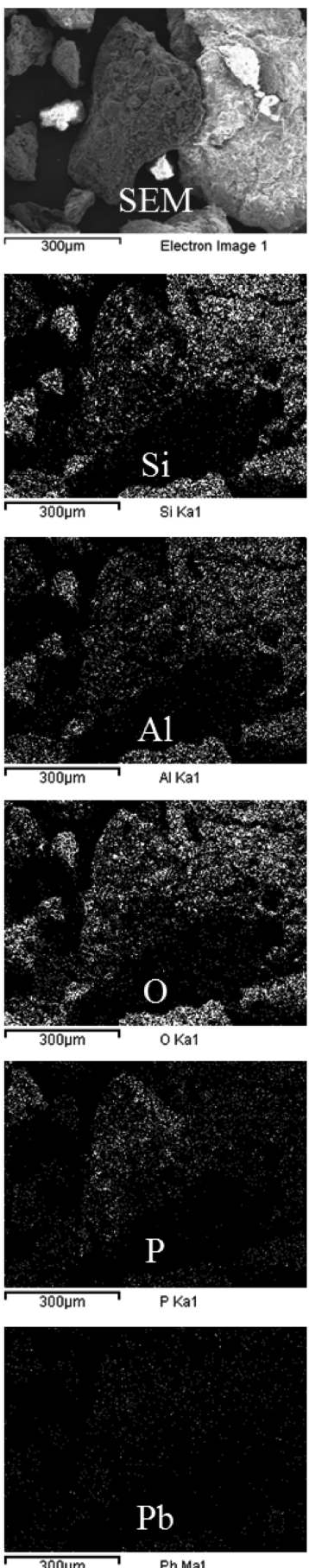

Fig. 5 Scanning electron microscopy (SEM) images and elemental dot maps $(\mathrm{Si}, \mathrm{Al}, \mathrm{O}, \mathrm{P}$ and $\mathrm{Pb}$ ) of the soil treated with (A) 10 wt\% of poultry manure (PM), (B) $10 \mathrm{wt} \%$ of poultry manure biochar pyrolyzed at $300^{\circ} \mathrm{C}(\mathrm{PBC} 300)$ and $(\mathrm{C}) 10 \mathrm{wt} \%$ of poultry manure biochar pyrolyzed at $700^{\circ} \mathrm{C}$ (PBC700).

토양 내 $\mathrm{DOC}$ 와 관련된 것으로 판단되었다. 그러나 $\mathrm{PBC700}$ 처 리구의 경우 납, 카드뮴, 아연, 구리의 농도가 모두 감소하여 안 정화되었으며, 무처리구 대비 감소율은 각각 7-23, 11-38, 11$52,19-36 \%$ 으로 나타났다. MINTEQ을 이용한 열역학 모델링 결과 $\mathrm{PBC} 70010.0 \mathrm{wt} \%$ 처리구에서는 납과 구리 화학종의 경
우 수산화물인 $\mathrm{Pb}(\mathrm{OH})_{2}, \mathrm{Cu}(\mathrm{OH})_{2}$ 의 침전이 예상되었다. 특히, 납의 경우 매우 낮은 용해도를 보유한 chloropyromorphite $\left[\mathrm{Pb}_{5}\left(\mathrm{PO}_{4}\right)_{3} \mathrm{Cl}\right]$, hydroxypyromorphite $\left[\mathrm{Pb}_{5}\left(\mathrm{PO}_{4}\right)_{3} \mathrm{OH}\right]$ 등의 침전이 예상되었다. 이와 함께 SEM-elemental dot mapping을 이용한 원소분포 조사 결과, 다른 처리구와 달리 $\mathrm{PBC} 700$ 처리구의 경 
우 납과 인의 분포부분이 중첩되어 두 원소간의 연관성이 있는 것으로 판단되었다. 이를 종합할 때, $\mathrm{PBC} 700$ 처리구의 납 용 출 농도의 감소는 $\mathrm{PBC} 700$ 이 함유한 인과 오염토양에 존재하는 납이 매우 안정한 형태의 화학종인 chloropyromorphite, hydroxypyromorphite 등을 형성하면서 나타난 결과로 판단된다.

Keywords amendment $\cdot$ black carbon $\cdot$ charcoal $\cdot$ metal stabilization $\cdot$ poultry manure $\cdot$ pyromorphite

감사의 글 본 연구는 2012년도 정부(교육과학기술부)의 재원으로 한국연구 재단의 기초연구사업 지원을 받아 수행되었습니다(과제번호 2012 R1A1B3001409). 시료의 기기분석은 한국기초과학지원연구원, 서울대학교 기초과학공동기기원, 강원대학교 공동실험실습관 및 강원대학교 환경연구소 에서 수행되었습니다.

\section{References}

Abd El-Azeem SAM, Ahmad M, Usman ARA, Kim KR, Oh SE, Lee SS et al. (2013) Changes of biochemical properties and heavy metal bioavailability in soil treated with natural liming materials. Environ Earth Sci 70, 3411-20.

Adriano DC (2001) Trace elements in terrestrial environments, second edition. Springer-Verlag, USA.

Ahmad M, Hashimoto Y, Moon DH, Lee SS, and Ok YS (2012a) Immobilization of lead in a Korean military shooting range soil using eggshell waste: an integrated mechanistic approach. $J$ Hazard Mater 209-210, 392-401.

Ahmad M, Lee SS, Dou X, Mohan D, Sung JK, Yang JE et al. (2012b) Effects of pyrolysis temperature on soybean stover- and peanut shellderived biochar properties and TCE adsorption in water. Bioresour Technol 118, 536-44.

Ahmad M, Lee SS, Lim JE, Lee SE, Cho JS, Moon DH et al. (2014a) Speciation and phytoavailability of lead and antimony in a small arms range soil amended with mussel shell, cow bone and biochar: EXAFS spectroscopy and chemical extractions. Chemosphere 95, 433-41.

Ahmad M, Lee SS, Yang JE, Ro HM, Lee YH, and Ok YS (2012c) Effects of soil dilution and amendments (mussel shell, cow bone, and biochar) on $\mathrm{Pb}$ availability and phytotoxicity in military shooting range soil. Ecotoxicol Environ Saf 79, 225-31.

Ahmad M, Rajapaksha AU, Lim JE, Zhang M, Bolan N, Mohan D et al (2014b) Biochar as a sorbent for contaminant management in soil and water: A review. Chemosphere 99, 19-33.

Ahmad M, Usman ARA, Lee SS, Kim SC, Joo JH, Yang JE et al. (2012d) Eggshell and coral wastes as low cost sorbents for the removal of $\mathrm{Pb}^{2+}$, $\mathrm{Cd}^{2+}$ and $\mathrm{Cu}^{2+}$ from aqueous solutions. $J$ Ind Eng Chem 18, 198-204.

Almaroai YA, Usman ARA, Ahmad M, Kim KR, Moon DH, Lee SS et al. (2012) Effects of synthetic chelators and low-molecular-weight organic acids on chromium, copper, and arsenic uptake and translocation in maize (Zea mays L.). Soil Sci 177, 655-63.

Almaroai YA, Usman ARA, Moon DH, Cho JS, Joo YK, Jeon C et al. (2014a) Effects of biochar, cow bone, and eggshell on $\mathrm{Pb}$ availability to maize in contaminated soil irrigated with saline water. Environ Earth Sci 71, 1289-96.

Almaroai YA, Vithanage M, Rajapaksha AU, Lee SS, Dou X, Lee YH et al. (2014b) Natural and synthesized iron-rich amendments for $\mathrm{As}$ and $\mathrm{Pb}$ immobilization in agricultural soil. Chem Ecol 30, 267-79.

Amonette JE and Joseph S (2009) Characteristics of biochar: Microchemical properties. In Biochar for Environmental Management Science and Technology, Lehmann J and Joseph S, pp. 33-52. Earthscans, UK.

Brallier S, Harrison RB, Henry CL, and Dongsen X (1996) Liming effects on availability of $\mathrm{Cd}, \mathrm{Cu}, \mathrm{Ni}$ and $\mathrm{Zn}$ in a soil amended with sewage sludge 16 years previously. Water Air Soil Pollut 86, 195-206.

Cantrell KB, Hunt PG, Uchimiya M, Novak JM, and Ro KS (2012) Impact of pyrolysis temperature and manure source on physicochemical characteristics of biochar. Bioresour Technol 107, 419-28.

Cao X and Harris W (2010) Properties of dairy-manure-derived biochar pertinent to its potential use in remediation. Bioresour Technol 101, $5222-8$.

Cao X, Ma L, Liang Y, Gao B, and Harris W (2011) Simultaneous immobilization of lead and atrazine in contaminated soils using dairymanure biochar. Environ Sci Technol 45, 4884-9.

Chan KY and $\mathrm{Xu} \mathrm{Z} \mathrm{(2009)} \mathrm{Biochar:} \mathrm{Nutrient} \mathrm{properties} \mathrm{and} \mathrm{their}$ enhancement. In Biochar for Environmental Management Science and Technology, Lehmann J and Joseph S, pp. 67-84. Earthscans, UK.

Coates J (2000) Interpretation of infrared spectra, a practical approach. In Encyclopedia of Analytical Chemistry, Meyers RA, pp. 10815-37. John Wiley \& Sons Ltd, UK.

Gee GW and Or D (2002) Particle-size analysis. In Methods of soil analysis, Part 4-Physical methods, Dane JH and Topp GC, pp. 255-93. Soil Science Society of America, Inc., Madison, USA.

Glaser B, Lehmann J, and Zech W (2002) Ameliorating physical and chemical properties of highly weathered soils in the tropics with charcoal - a review. Biol Fertil Soils, 35, 219-30.

Gustafsson JP (2012) Visual MINTEQ ver. 3.0. KTH. Sweden.

Hashimoto Y, Matsufuru H, Takaoka M, Tanida H, and Sato T (2009) Impacts of chemical amendment and plant growth on lead speciation and enzyme activities in a shooting range soil: an X-ray absorption fine structure investigation. J Environ Qual 38, 1420-8.

Khan S, Chao C, Waqas M, Arp HPH, and Zhu YG (2013) Sewage sludge biochar influence upon rice (Oryza sativa $\mathrm{L}$ ) yield, metal bioaccumulation and greenhouse gas emissions from acidic paddy soil. Environ Sci Technol 47, 8624-32.

Kostarelos K, Reale D, Dermatas D, Rao E, and Moon DH (2006) Optimum dose of lime and fly ash for treatment of hexavalent chromiumcontaminated soil. Water Air Soil Poll: Focus 6, 171-89.

Kumpiene J, Lagerkvist A, and Maurice C (2008) Stabilization of As, Cr, Cu, $\mathrm{Pb}$ and $\mathrm{Zn}$ in soil using amendments - A review. Waste Manag 28, 21525.

Lee SH, Lee JS, Choi YJ, and Kim JG (2009) In situ stabilization of cadmium-, lead-, and zinc-contaminated soil using various amendments. Chemosphere 77, 1069-75.

Lee SS, Lim JE, Abd El-Azeem SAM, Choi B, Oh SE, Moon DH et al. (2013) Heavy metal immobilization in soil near abandoned mines using eggshell waste and rapeseed residue. Environ Sci Pollut Res 20, 171926.

Lehmann J (2007) A handful of carbon. Nature 447, 143-4.

Lehmann J and Joseph S (2009) Biochar for Environmental Management Science and Technology. Earthscans, UK.

Lim JE, Ahmad M, Lee SS, Shope CL, Hashimoto Y, Kim KR et al. (2013a) Effects of lime-based waste materials on immobilization and phytoavailability of cadmium and lead in contaminated soil. Clean 41, $1235-41$.

Lim JE, Ahmad M, Usman ARA, Lee SS, Jeon WT, Oh SE et al. (2013b) Effect of natural and calcined poultry waste on $\mathrm{Cd}, \mathrm{Pb}$ and As mobility in contaminated soil. Environ Earth Sci 69, 11-20.

Lim JE, Kim HW, Jeong SH, Lee SS, Yang JE, Kim KH et al. (2014) Characterization of burcucumber biochar and its potential as an adsorbent for veterinary antibiotics in water. $J$ Appl Biol Chem 57, 6572.

MAFRA (2013) Medium- and long-term countermeasure for recycling of livestock manure. Ministry of Agriculture, Food and Rural Affairs. Korea.

MOE (2014) The Korean warning standard for agricultural land. Ministry of Environment, Korea.

Mohan D, Sarswat A, Ok YS, and Pittman Jr CU (2014) Organic and inorganic contaminants removal from water with biochar, a renewable, low cost and sustainable adsorbent - A critical review. Bioresour Technol 160, 191-202.

Moon DH, Kim KY, Yoon IH, Grubb DG, Shin DY, Cheong KH et al. (2011) Stabilization of arsenic-contaminated mine tailings using natural and calcined oyster shells. Environ Earth Sci 64, 597-605. 
Moon DH, Park JW, Chang YY, Ok YS, Lee SS, Ahmad M et al. (2013) Immobilization of lead in contaminated firing range soil using biochar Environ Sci Pollut Res 20, 8464-71.

Moon DH, Wazne M, Yoon IH, and Grubb DG (2008) Assessment of cement kiln dust (CKD) for stabilization/solidification (S/S) of arsenic contaminated soils. J Hazard Mater 159, 512-8.

NAAS (2014) Korean Soil Information System. National Academy of Agricultural Science, Korea.

NIAST (2000) Method of Soil and Plant Analysis. National Institute of Agricultural Science and Technology. Korea.

Novak JM, Lima I, Xing B, Gaskin JW, Steiner C, Das KC et al. (2009) Characterization of designer biochar produced at different temperatures and their effects on a loamy sand. Ann Environ Sci 3, 195-206.

Ok YS, Lee SS, Jeon WT, Oh SE, Usman ARA, and Moon DH (2011a) Application of eggshell waste for the immobilization of cadmium and lead in a contaminated soil. Environ Geochem Health, 33, 31-9.

Ok YS, Oh SE, Ahmad M, Hyun S, Kim KR, Moon DH et al. (2010) Effects of natural and calcined oyster shells on $\mathrm{Cd}$ and $\mathrm{Pb}$ immobilization in contaminated soils. Environ Earth Sci 61, 1301-8.

Ok YS, Usman ARA, Lee SS, Abd El-Azzem SAM, Choi B, Hashimoto Y et al. (2011b) Effects of rapeseed residue on lead and cadmium availability and uptake by rice plants in heavy metal contaminated paddy soil. Chemosphere 85, 677-82.

Ortiz Escobar ME and Hue NV (2008) Temporal changes of selected chemical properties in three manure-amended soils of Hawaii. Bioresour Technol 99, 8649-54.

Pérez-Esteban J, Escolástico C, Masaguer A, Vargas C, and Moliner A (2014) Soluble organic carbon and $\mathrm{pH}$ of organic amendments affect metal mobility and chemical speciation in mine soils. Chemosphere 103, 164 71

Ryan JA, Zhang P, Hesterberg D, Chou J, and Sayers DE (2001) Formation of chloropyromorphite in a lead-contaminated soil amended with hydroxyapatite. Environ Sci Technol 35, 3798-803.

Shinogi Y and Kanri Y (2003) Pyrolysis of plant, animal and human waste: physical and chemical characterization of the pyrolytic products. Bioresour Technol 90, 241-7.

Uchimiya M, Lima IM, Klasson KT, Chang SC, Wartelle LH, and Rodgers JE (2010a) Immobilization of heavy metals ions $\left(\mathrm{Cu}^{\mathrm{II}}, \mathrm{Cd}^{\mathrm{II}}, \mathrm{Ni}^{\mathrm{II}}\right.$, and $\left.\mathrm{Pb}^{\mathrm{II}}\right)$ by broiler litter-derived biochars in water and soil. J Agric Food Chem 58, 5538-44.

Uchimiya M, Wartelle LH, Lima IM, and Klasson KT (2010b) Sorption of deisopropylatrazine on broiler litter biochars. J Agric Food Chem 58, $12350-6$.

USEPA (1992) Toxicity characteristic leaching procedure. Method 1311, United States Environmental Protection Agency, USA.

Usman ARA, Almaroai YA, Ahmad M, Vithanage M, and Ok YS (2013) Toxicity of synthetic chelators and metal availability in poultry manure amended $\mathrm{Cd}, \mathrm{Pb}$, and As contaminated agricultural soil. J Hazard Mater 262, 1022-30.

Wong JWC, Li KL, Zhou LX, and Selvam A (2007) The sorption of Cd and $\mathrm{Zn}$ by different soils in the presence of dissolved organic matter from sludge. Geoderma 137, 310-7.

Yuan JH, Xu RK, and Zhang H (2011) The forms of alkalis in the biochar produced from crop residues at different temperatures. Bioresour Technol 102, 3488-97.

Zhang T, Walawender WP, Fan LT, Fan M, Daugaard D, and Brown RC (2004) Preparation of activated carbon from forest and agricultural residues through $\mathrm{CO}_{2}$ activation. Chem Eng $J$ 105, 53-9.

Zhao XL and Masaihiko S (2007) Amelioration of cadmium polluted paddy soils by porous hydrated calcium silicate. Water Air Soil Pollut 183, $309-15$.

Zhou LX and Wong JWC (2001) Effect of dissolved organic matter from sludge and sludge compost on soil copper sorption. J Environ Qual 30, 878-83. 